\title{
REVIEW
}

\section{Ecology and pathology of amphibian ranaviruses}

\author{
Matthew J. Gray ${ }^{1, *}$, Debra L. Miller ${ }^{1,2}$, Jason T. Hoverman ${ }^{1}$ \\ ${ }^{1} 274$ Ellington Plant Sciences Building, Center for Wildlife Health, Department of Forestry Wildlife and Fisheries, \\ Institute of Agriculture, University of Tennessee, Knoxville, Tennessee 37996-4563, USA \\ ${ }^{2}$ Veterinary Diagnostic and Investigational Laboratory, College of Veterinary Medicine, University of Georgia, \\ 43 Brighton Road, Tifton, Georgia 31793, USA
}

\begin{abstract}
Mass mortality of amphibians has occurred globally since at least the early 1990s from viral pathogens that are members of the genus Ranavirus, family Iridoviridae. The pathogen infects multiple amphibian hosts, larval and adult cohorts, and may persist in herpetofaunal and osteichthyan reservoirs. Environmental persistence of ranavirus virions outside a host may be several weeks or longer in aquatic systems. Transmission occurs by indirect and direct routes, and includes exposure to contaminated water or soil, casual or direct contact with infected individuals, and ingestion of infected tissue during predation, cannibalism, or necrophagy. Some gross lesions include swelling of the limbs or body, erythema, swollen friable livers, and hemorrhage. Susceptible amphibians usually die from chronic cell death in multiple organs, which can occur within a few days following infection or may take several weeks. Amphibian species differ in their susceptibility to ranaviruses, which may be related to their co-evolutionary history with the pathogen. The occurrence of recent widespread amphibian population die-offs from ranaviruses may be an interaction of suppressed and naïve host immunity, anthropogenic stressors, and novel strain introduction. This review summarizes the ecological research on amphibian ranaviruses, discusses possible drivers of emergence and conservation strategies, and presents ideas for future research directions. We also discuss common pathological signs of ranaviral disease, methods for diagnostic evaluation, and ranavirus surveillance methods. Inasmuch as ranaviral disease is listed as a notifiable disease by the World Organization for Animal Health and is a threat to amphibian survival, we recommend that biosecurity precautions are implemented by nations to reduce the likelihood of transporting ranavirus virions among populations. Biosecurity precautions include disinfecting footwear and equipment that comes in contact with surface water inhabited by amphibians and testing commercially shipped amphibians for the pathogen. We also encourage natural resource organizations to establish routine surveillance programs for ranaviruses in wild amphibian populations.
\end{abstract}

KEY WORDS: Ambystoma tigrinum virus · Anuran · Bohle iridovirus · Urodela $\cdot$ Emerging infectious disease $\cdot$ Frog virus $3 \cdot$ Iridovirus $\cdot$ Salamander

Resale or republication not permitted without written consent of the publisher

\section{INTRODUCTION}

Amphibian populations are declining globally (Houlahan et al. 2000, Stuart et al. 2004). While there are a number of factors that have contributed to these declines, emerging infectious diseases have been linked to single- and multiple-population die-offs
(Collins \& Storfer 2003, Daszak et al. 2003, Wake \& Vredenburg 2008). Batrachochytrium dendrobatidis and several viral types within the genus Ranavirus have been associated with most of the reported amphibian mass mortality events (Berger et al. 1998, Green et al. 2002, Carey et al. 2003a). Ranavirus-associated mortality has been reported on 5 continents, at all lati- 
tudes and elevations that amphibians inhabit, and in most of the major families of Anura and Urodela (Carey et al. 2003a,b, Daszak et al. 2003). Since determining that ranaviruses were an etiologic agent in amphibian die-offs in the early 1990s (Cunningham et al. 1993, 1996, Drury et al. 1995, Jancovich et al. 1997), scientists have been conducting studies on the genetics, ecology, and pathology of this pathogen to determine factors that may lead to its emergence.

The ecology of ranaviruses likely involves a complex interaction of reservoir species, transmission routes, environmental persistence, stressors, and host immunity (Fig. 1). Given the growing interest in the effects of pathogens on amphibians, our goal was to summarize the existing literature on the ecology and pathology of ranaviruses that infect amphibians and to provide ideas for conservation strategies and future research directions. Included is a summation of the current understanding of Ranavirus genetics; however, we do not provide a detailed description of taxonomy or molecular biology, because extensive reviews and analyses on these topics have been provided previously (e.g. Chinchar 2002, Wang et al. 2003, Williams et al. 2005, Chinchar \& Hyatt 2008, Chinchar et al. 2009). We also do not critique molecular techniques used to differentiate ranaviruses; however, we raise some potential limitations of techniques and direct readers to molecular reviews over ranaviruses for details on caveats.

\section{AMPHIBIAN DIE-OFFS AND RANAVIRUSES}

Mass mortality of amphibians from ranaviruses have been reported in the Americas, Europe, and Asia (Cunningham et al. 1996, Carey et al. 2003a, Converse \& Green 2005a, Green \& Converse 2005, Fox et al. 2006, Ariel et al. 2009, Balseiro et al. 2009, Une et al. 2009). Ranaviruses also have been isolated from wildcaptured amphibians in Australia (Speare \& Smith 1992, Cullen \& Owens 2002), but die-offs in the wild from ranaviruses are unknown on this continent. The greatest number of reported die-offs is from North America, where ranaviruses are responsible for amphibian mortality events in 3 Canadian provinces and over 20 states in the USA (Bollinger et al. 1999, Green et al. 2002, Carey et al. 2003a, Greer et al. 2005, Jancovich et al. 2005). Muths et al. (2006) reported that $43 \%$ of the reported die-offs in the USA from 2000 to 2005 were due to ranaviruses. Similarly, Green et al. (2002) reported that $57 \%$ of the mortality events investigated by the United States Geological Survey National Wildlife Health Center from 1996 to 2001 were wholly or partially caused by ranaviruses. It is estimated that from 1 to 3 new states in the USA report ranavirus die-offs each year (Converse \& Green 2005a). Together these data suggest that ranaviruses are widespread pathogens that are frequently associated with amphibian die-offs.

Whether ranaviruses represent a significant threat to amphibian biodiversity is currently debated. The importance of ranaviruses in amphibian epizootics has been frequently dismissed, because most ranavirusassociated mortality has occurred with common species (Cunningham et al. 1996, Green et al. 2002, Carey et al. 2003a, Muths et al. 2006). Although the likelihood of detection can be low, die-offs have been reported in uncommon species. For example, Rana muscosa, R. aurora, Anaxyrus (formerly Bufo) boreas, and Ambystoma tigrinum stebbinsi are species of conservation concern in North America that have experienced die-offs from ranaviruses (Jancovich et al. 1997, Converse \& Green 2005a). Thus, die-offs of uncommon species may occur more frequently than realized. Ranaviruses can impact population structure and the likelihood of species persistence (Collins et al. 1988, Schock \& Bollinger 2005) by causing annual mass mortality events (Berna 1990, Cunningham et al. 1996, Bollinger et al. 1999, Brunner et al. 2004, Greer et al. 2005, Teacher 2008). This threat is especially high for less abundant species, where repeated failed recruitment could result in local extirpation (Power \& Mitchell 2004, de Castro \& Bolker 2005). While additional research addressing the population-level effects of ranaviruses on amphibians is needed, it is clear that ranaviruses are impacting both common and rare amphibian species across the landscape.

\section{RANAVIRUS CHARACTERISTICS}

Ranaviruses were first isolated from Lithobates (formerly Rana) pipiens in the mid-1960s (Granoff et al. 1965, Rafferty 1965). Ranavirus is in the family Iridoviridae (Eaton et al. 2007), which contains 5 genera: 2 infect invertebrates (Iridovirus and Chloriridovirus) and 3 infect ectothermic vertebrates (Ranavirus, Megalocytivirus, and Lymphocystivirus; Chinchar et al. 2009). Ranaviruses are large, double-stranded DNA viruses (ca. $105 \mathrm{kbp}, 150 \mathrm{~nm}$ diameter; Williams et al. 2005), with a distinctive icosahedral shape that is frequently visible in the cytoplasm of infected cells as paracrystalline arrays in electron microscopic images (Fig. 2; Chinchar \& Hyatt 2008). The replication cycle of ranaviruses has been studied extensively using frog virus 3 (FV3), which is the type species for the genus (Chinchar et al. 2005, 2009, Williams et al. 2005). The genome encodes around 100 putative gene products (Chinchar 2002), including several that likely play roles in virulence and immune evasion proteins (Chin- 
A)



B)

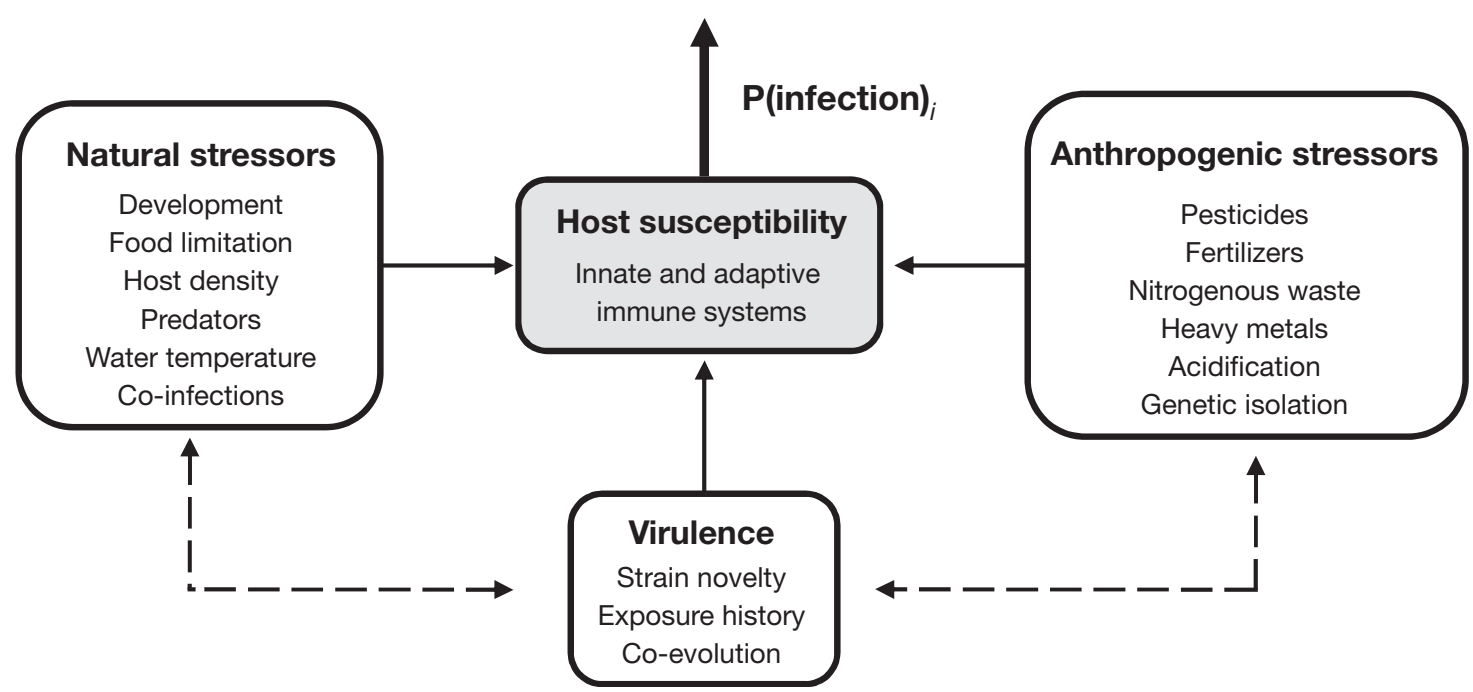

Fig. 1. Conceptual model of amphibian ranavirus ecology. (A) Transmission dynamics are impacted by infected, susceptible, and recovered host densities, persistence of shed virions in the environment, the likelihood of exposure through indirect (IT) and direct (DT) routes, and the susceptibility of each host age class $i$. Probability of survival, $\mathrm{P}(\mathrm{S})_{i}$ is dependent on developmental stage; referenced here according to Gosner (1960). (B) Probability of infection is an interaction of the probability of exposure (P[exposure], Panel A), natural and anthropogenic stressors, and type virulence. Solid and dotted lines are known and unknown routes or effects, respectively 




Fig. 2. Transmission electron microscopic (TEM) image of a Ranavirus paracrystalline array within the cytoplasm of an infected cell; inset shows a single virion from cell culture, negatively stained, and examined by TEM. Photograph by Eloise Styer of the University of Georgia Veterinary Diagnostic and Investigational Laboratory, Tifton

char et al. 2009). Viral replication for FV3 occurs between 12 and $32^{\circ} \mathrm{C}$, with viral protein synthesis occurring within hours of cell infection (Chinchar 2002). Cell death can occur as quickly as a few hours following infection, by either necrosis or apoptosis (Chinchar et al. 2003, Williams et al. 2005). At the level of the host, ranavirus populations grow quickly. Brunner et al. (2005) estimated that the doubling rate of ranaviruses in a salamander host was from 0.7 to $1.8 \mathrm{~d}$.

Ranaviruses are known to infect amphibians, reptiles, and osteichthyan (bony) fish (Fig. 1A; Williams et al. 2005). Currently, 6 species of Ranavirus are recognized 3 of which infect amphibians: FV3, Bohle iridovirus (BIV) and Ambystoma tigrinum virus (ATV; Chinchar et al. 2005). Majji et al. (2006) also provided evidence of a fourth possible species that infects amphibians (Rana catesbeiana virus Z, RCV-Z) based on restriction fragment length polymorphism (RFLP) profiles. The entire genomes of 2 species (FV3 and ATV) and 1 type of FV3 (tiger frog virus) have been sequenced (He et al. 2002, Jancovich et al. 2003, Tan et al. 2004). The major capsid protein (MCP) comprises about half the weight of the virion (Hyatt et al. 2000). This protein is highly conserved among Ranavirus species, and an antibody raised against the MCP of one species often cross reacts with other members of the genus (Hedrick et al. 1992). A 500 bp region at the $5^{\prime}$ end of the MCP gene is commonly sequenced to characterize Ranavirus species (Mao et al. 1996, Tidona et al. 1998, Chinchar 2002). Although frequently done, sequence analysis based solely on a $500 \mathrm{bp}$ region of the MCP (ca. $0.3 \%$ of the genome) is not definitive evidence that an isolate or PCR product is a particular Ranavirus species. The assignment of a Ranavirus species should be based on multiple criteria, including host range, sequence determination, and RFLP and protein profiles (Williams et al. 2005).

At least 30 isolates of Ranavirus have been mapped phylogenetically, with over half infecting amphibians (Hyatt et al. 2000, Wang et al. 2003). Genetic variation of the MCP gene for FV3-like isolates seems to be less than for ATV-like isolates (Schock et al. 2008). While significant geographic variation of the MCP and other genes in ATV has been reported (Jancovich et al. 2005, Ridenhour \& Storfer 2008), FV3 seems to be more genetically conserved across regions and species (Schock et al. 2008).

It is hypothesized that genetically unique isolates may represent novel Ranavirus types that have enhanced virulence (Ridenhour \& Storfer 2008). Type virulence is likely related to genetic similarity with amphibian host cells. Schock et al. (2008) demonstrated that ATV and FV3 infected multiple species, but these ranaviruses were most virulent within the orders Urodela and Anura, respectively, from which they were isolated. Variation in susceptibility to ranaviruses also exists among populations for a species (Brunner et al. 2005, Pearman \& Garner 2005), and may be related to exposure history (Teacher et al. 2009a). Teacher et al. (2009a) provided the first evidence of directional selection against alleles that connote high susceptibility in Rana temporaria populations that experienced repeated die-offs from ranaviruses. Populations that experienced ranavirus die-offs were more homozygous than populations that had not experienced die-offs from ranavirus, which was attributed to positive assortative mating instead of a bottleneck effect (Teacher et al. 2009b).

Infection by ranaviruses does not always result in mortality (Miller et al. 2009). Laboratory and field studies confirm that individuals can be sublethally infected with ranaviruses (Brunner et al. 2004, Pearman et al. 2004, Gray et al. 2007, Greer et al. 2009). Exposure to ranaviruses appears to induce an adaptive immune 
response in anurans that connotes enhanced immunity to repeated viral exposure if the individual survives. Gantress et al. (2003) quantified the immune response of Xenopus laevis to repeated FV3 infections. Adult $X$. laevis were able to clear FV3 in 1 mo and $3 \mathrm{~d}$ following first and second exposures, respectively. Rapid clearing during the second exposure may be due to a strong anti-FV3 antibody response of the IgY isotype (Gantress et al. 2003, Maniero et al. 2006). Antibody production against ranaviruses also has been found in Chaunus marinus from Australia and Venezuela (Zupanovic et al. 1998). Majji et al. (2006) demonstrated that Ranavirus RCV-Z was less pathogenic to Lithobates catesbeianus (formerly Rana catesbeiana) tadpoles when exposed first to FV3. Thus, the likelihood of an amphibian experiencing mortality due to exposure to multiple ranaviruses is probably a result of type virulence and exposure order (Fig. 1B).

\section{POSSIBLE RESERVOIRS}

\section{Intra-class reservoirs}

Amphibians are one of the primary reservoirs of ranaviruses (Fig. 1A). Given the biphasic life cycle of many amphibians (Wilbur 1984), amphibian reservoirs could occur in aquatic or terrestrial environments. In aquatic environments, amphibian species with larvae that develop over more than 1 season (e.g. Lithobates catesbeianus; Gray et al. 2007), with paedomorphic development (e.g. Ambystoma tigrinum; Jancovich et al. 1997), or with highly aquatic adults (e.g. Notophthalmus viridescens, Desmognathus quadramaculatus; Duffus et al. 2008, Gray et al. 2009) are likely reservoirs. Gray et al. (2007) reported that $57 \%$ of overwintering L. catesbeianus tadpoles were positive for a ranavirus, and few exhibited pathological signs (Miller et al. 2009). We also have documented Ranaviruspositive $D$. quadramaculatus adults in the field, with few pathological signs noted (Gray et al. 2009). Thus, larval and adult amphibians in the aquatic environment may contribute to maintaining ranaviruses in a system (Duffus et al. 2008).

In temporary wetlands or in amphibian communities where larvae or adults do not overwinter in the aquatic environment, postmetamorphic cohorts may be important reservoirs. Brunner et al. (2004) demonstrated in the laboratory that salamander larvae exposed to ATV could survive through metamorphosis with sublethal infections, providing evidence that juvenile salamanders might function as reservoirs. This finding was supported by field data at 1 breeding site, where $78 \%$ of emigrating salamander metamorphs were ATV positive, and, in the subsequent year, $7 \%$ of immigrating salamanders tested positive for ATV (Brunner et al. 2004). We found that 56 of 69 adult plethodontid salamanders (10 species total) tested positive for Ranavirus in the Great Smoky Mountains National Park (Gray et al. 2009). In Europe and Australia, adult anurans are known to be suitable hosts of ranaviruses (Cullen \& Owens 2002, Cunningham et al. 2007a,b, Ariel et al. 2009). These studies illustrate that postmetamorphic amphibians may have an important role in maintaining ranaviruses in host populations among years (Brunner et al. 2004).

Whether an amphibian species maintains persistent ranavirus infections or experiences mortality is probably a consequence of species-specific immune response and life history. We hypothesize that species inhabiting permanent wetlands with larvae that have long development times are less likely to experience morbidity from ranaviruses due to acquired immunity from repeated exposure over multiple generations. Although mass mortality of Lithobates catesbeianus tadpoles has been reported in aquaculture facilities (Miller et al. 2007), this species appears to fit this model. After $4 \mathrm{wk}$, we documented $6 \%$ mortality and $6 \%$ infection in L. catesbeianus tadpoles orally inoculated with $10^{6}$ plaque-forming units (PFU) of FV3 (authors' unpubl. data). In contrast, 90 and $60 \%$ of Lithobates (formerly Rana) palustris and Hyla chrysoscelis tadpoles, respectively, died within $2 \mathrm{wk}$ following oral inoculation of the same FV3 isolate and dose (authors' unpubl. data). Tadpoles of L. palustris and $H$. chrysoscelis have short developmental times compared to L. catesbeianus. These species also inhabit more ephemeral breeding sites than L. catesbeianus, where ranaviruses may be less prevalent due to fewer reservoirs. We hypothesize that $L$. catesbeianus tadpoles likely represent a significant ranavirus reservoir, which has been suggested for other pathogens such as Batrachochytrium dendrobatidis (Daszak et al. 2004, Hanselmann et al. 2004, Garner et al. 2006).

\section{Other reservoirs}

Fish and reptiles may be reservoirs for amphibian ranaviruses (Fig. 1A). The amphibian Ranavirus BIV has been shown to cause disease in the barramundi Lates calcarifer (Moody \& Owens 1994) and in tilapia Oreochromis mossambicus (Ariel \& Owens 1997). The pike Esox lucius became infected when exposed to FV3, but ranaviral disease did not develop (Bang Jensen et al. 2009). Mao et al. (1999) also provided molecular evidence that ranaviruses isolated from sympatric moribund stickleback fish Gasterosteus aculeatus and a Rana aurora tadpole were identical. However, sunfish Lepomis cyanellus and mosquito fish 
Gambusia affinis did not become infected when exposed to ATV (Jancovich et al. 2001). These studies suggest that whether fish are a reservoir of amphibian ranaviruses may depend on the type of Ranavirus and the fish host.

The first reported case of an iridovirus infecting a free-ranging reptile was from a gopher tortoise Gopherus polyphemus (Westhouse et al. 1996). Subsequently, iridoviruses that share $>96 \%$ MCP gene sequence identity with amphibian ranaviruses have been detected in Hermann's tortoises Testudo hermanni (Marschang et al. 1999), eastern box turtles Terrapene carolina carolina (De Voe et al. 2004, Allender et al. 2006, Johnson et al. 2008), soft-shelled turtles Trionyx sinensis (Zhao et al. 2007), leaf-tailed geckos Uroplatus fimbriatus (Marschang et al. 2005), and green pythons Chondropython viridis (Hyatt et al. 2002). Whether or not the iridoviruses infecting reptiles can be genetically classified as a Ranavirus is debatable, because most studies only sequenced a small portion of the MCP. Moreover, it is unknown if iridoviruses that infect reptiles can cause disease in amphibians. However, Ariel (1997) experimentally challenged juveniles of the tortoise species Emydura krefftii and Elseya latisternum with BIV and found they were highly susceptible. These studies raise the intriguing possibility that amphibian ranaviruses may be maintained by reptiles, but more research is needed.

\section{TRANSMISSION}

Pathogen transmission is fundamental to understanding the ecology and evolution of host-pathogen interactions (McCallum et al. 2001). Predictions from models of host-pathogen dynamics, as well as conception of management strategies that reduce disease risk, depend on the route and form of transmission. Transmission includes a combination of indirect and direct routes, with the former dependent on virion persistence in the environment (Fig. 1A). Below, we summarize what is currently known about how amphibians contract ranavirus infections.

\section{Indirect transmission}

Amphibians can become infected with pathogens circulating in the environment. Water and sediment can be effective routes of pathogen transmission, especially for amphibians that use ponds as larvae or adults. Harp \& Petranka (2006) successfully infected Lithobates sylvaticus (formerly Rana sylvatica) tadpoles by exposing them to sediment collected from a site where a ranavirus die-off was occurring. Exposure to salamander larvae infected with ATV can result in infection of conspecifics in $<24 \mathrm{~h}$ without any direct contact (Greer et al. 2008). Salamanders exposed to ATV in a water bath appear to become infectious to other individuals within $2 \mathrm{~d}$, with their infectious capability increasing through time up to their death (Brunner et al. 2007). These studies suggest that virions shed into the aquatic environment can successfully infect new amphibian hosts, with infection most likely occurring across epithelial surfaces (e.g. intestinal mucosa, gill lamellae).

The persistence of ranaviruses outside the amphibian host is poorly understood, but fundamental to indirect transmission dynamics. Virions of ATV might persist in the environment for up to $2 \mathrm{wk}$ (Jancovich et al. 1997, Collins et al. 2004). This duration may be shorter if water at a breeding site evaporates. Brunner et al. (2007) found that moist soil inoculated with ATV $\left(2 \times 10^{7} \mathrm{PFU}\right)$ was unable to cause infection in larval salamanders if the soil was dried for $4 \mathrm{~d}$ and rehydrated prior to host exposure. In contrast, soil inoculated with virus that remained moist caused $87 \%$ mortality of larval salamanders over the same duration (Brunner et al. 2007). Thus, virions may persist in the soil at breeding sites if the soil remains moist. One shortcoming of the above studies is that the virus was not cultured from the water or soil; thus, viable virions may have persisted yet not resulted in organism infection. Langdon (1989) investigated the environmental persistence of epizootic hematopoietic necrosis virus (EHNV), which is an iridovirus known to infect fish and is closely related to amphibian ranaviruses (Langdon et al. 1986, Mao et al. 1999, Wang et al. 2003). Langdon (1989) cultured EHNV from distilled water after $97 \mathrm{~d}$, from dry infected tissue stored at $15^{\circ} \mathrm{C}$ after $113 \mathrm{~d}$, and from infected fish tissue stored at $-20^{\circ} \mathrm{C}$ after $2 \mathrm{yr}$. While the potential exists for amphibian ranaviruses to persist for long durations in the environment, more research is needed on the difference in environmental persistence of ranavirus virions at permanently versus temporarily flooded breeding sites. Information also is needed on virion concentration in the environment during and prior to amphibian die-offs. Estimating viral loads in the environment can be challenging considering that die-offs often go undetected, especially in larval populations (Green et al. 2009). Laboratory studies suggest that an environmentally relevant concentration of ranavirus virions in water contaminated by infected salamanders may be from $10^{3}$ to $10^{4} \mathrm{PFU} \mathrm{ml} \mathrm{m}^{-1}$ (Rojas et al. 2005).

\section{Direct transmission}

Direct transmission of ranaviruses is highly effective in amphibians. Ingestion of morbid and dead individuals infected with ranavirus is common (Pearman et al. 
2004, Harp \& Petranka 2006). Some larval species (e.g. Ambystoma tigrinum, Spea multiplicata) have cannibalistic phenotypes (Hoffman \& Pfennig 1999, Pfennig \& Murphy 2000), and many amphibian species consume embryos (Alford 1999), which can be infected with ranavirus (Tweedell \& Granoff 1968). Several studies have documented that ingestion of ranavirus-infected animal tissue can cause infection (Jancovich et al. 1997, Pearman et al. 2004, Harp \& Petranka 2006, Brunner et al. 2007, Cunningham et al. 2007a). Thus, ranaviruses may limit the occurrence of cannibalistic phenotypes in amphibian populations through differential survival (Pfennig et al. 1991, Parris et al. 2005). Larval salamanders that were infected with ranavirus were depredated $48 \%$ less by dragonfly Anax junius larvae than controls (Parris et al. 2004), although the mechanism could not be identified. Failed predation attempts that damage skin may also facilitate indirect transmission of free-floating virions in the environment or direct transmission through contact with infected individuals. Transmission of ranavirus across damaged and intact skin has been shown (Brunner et al. 2007, Cunningham et al. 2007a). Brunner et al. (2007) demonstrated that $1 \mathrm{~s}$ of direct skin contact between infected and uninfected larval salamanders was sufficient to cause infection. Transmission of ranavirus among anuran metamorphs through direct contact has also been reported (Cullen et al. 1995).

Vertical transmission of ranaviruses involving infection of the egg or sperm in vivo in amphibians has not been proven. Docherty et al. (2003) isolated an iridovirus from the testes of a salamander, providing initial evidence that vertical transmission may be possible. Infection of eggs or sperm also might occur during transport to or in the cloaca from epithelial shedding of virions. However, postgametogenesis transmission generally is not considered vertical because unrelated individuals could be infected as well, especially if virions are shed from the vent. Duffus et al. (2008) detected a ranavirus-positive embryo from an egg mass that was produced by a positive male and negative female Lithobates sylvaticus. The route for transmission was unclear in their study, and contamination from cloacal or epidermal shedding of the virus from the male could not be ruled out. Several researchers have reported that eggs or captive tadpoles raised from egg masses collected in the wild tested positive for Ranavirus (Greer et al. 2005, Duffus et al. 2008). To date, a study has not been performed to test vertical transmission of ranaviruses in amphibians where in vitro contamination was controlled. At the population level, it may be unimportant whether infection of eggs or sperm occurs in the sex organs or subsequently via cloacal or epidermal shedding, considering that transmission during or after gametogenesis likely results in the same survival endpoint.

\section{STRESSORS}

Stressors are defined as factors that cause endogenous production of corticosteroid hormones in organisms, which can aid in short-term survival; however, chronic exposure to stressors can result in deleterious effects on the immune system (Hill \& Wyse 1989). In general, secretion of corticosterone and aldosterone causes immune suppression by decreasing T-cell proliferation and antibody production, and by inducing lymphocyte apoptosis (Rollins-Smith \& Blair 1993, Ottaviani \& Franceschi 1996, Ducoroy et al. 1999). Corticosteroids are produced during normal physiological processes, but their production also can be initiated in response to external stimuli (Carey et al. 1999). External stimuli can be natural stressors, such as changes in ambient temperature, food limitation, or threat of predation, or they can be anthropogenic in origin, such as decreases in water quality from agricultural operations. Stressors can increase the likelihood of pathogen infection and morbidity due to reduced immune function (Carey et al. 1999). Below we summarize the current understanding of the role that stressors play in the emergence of ranaviruses in amphibian populations, which likely includes a combination of natural and anthropogenic factors interacting with host immunity and type virulence (Fig. 1B).

\section{Natural stressors}

For amphibians, development represents a significant natural stressor. Changes in tadpole immunity during development have been extensively studied for Xenopus laevis (Rollins-Smith 1998). For this species, immunity increases from the embryo stages through tadpole pro-metamorphosis then decreases rapidly as endogenous corticosteroids are produced (Flajnik et al. 1987). It is hypothesized that natural immunosuppression associated with metamorphic climax is an adaptation to facilitate reconstruction of the organ systems for postmetamorphic life (Rollins-Smith 1998). The immune function at metamorphosis is probably lower than in all other developmental stages, and represents a period of high pathogen susceptibility (Carey et al. 1999). Mass mortality of larvae from ranaviruses has been reported frequently in anurans during metamorphosis (Speare \& Smith 1992, Green \& Converse 2005, Greer et al. 2005). Recently metamorphosed juveniles also appear to be highly susceptible (Cullen \& Owens 2002, Brunner et al. 2004, Schock et al. 2008). Following tail resorption, juvenile immunity increases until sexual maturity, with the adult immune function higher than in all other stages (Rollins-Smith 1998, Gantress et al. 2003). Gantress et al. (2003) demon- 
strated that adult $X$. laevis were able to resist high doses of FV3, with only transitory signs of disease. Others have reported greater infection rates and morbidity in tadpoles and juvenile amphibians compared to adults (Gruia-Gray \& Desser 1992, Cullen \& Owens 2002, Green et al. 2002, Collins et al. 2004). The trend for greater susceptibility of larvae and metamorphs compared to adults appears to be consistent among amphibian species, except for anurans in the UK. Cunningham et al. (1996, 2007a,b) have reported morbidity caused by ranaviruses in Rana temporaria and Bufo bufo adults only. High occurrence of adult mortality may be a consequence of easier detection, because most die-off reports are submitted by the public in the UK (A. G. F. Teacher, Royal Holloway, University of London, pers. comm.). The relative susceptibility of larval versus adult $R$. temporaria is the focus of ongoing controlled studies (A. A. Cunningham, Zoological Society of London, pers. comm.). Very little information is available about the susceptibility of early stages in amphibian development. Tweedell \& Granoff (1968) reported $>99 \%$ mortality for Lithobates pipiens embryos exposed to $10^{2}-10^{4} \mathrm{PFU}$ of FV3. However, in ongoing research at the University of Tennessee, we documented that the egg stage was least susceptible to ranavirus compared to hatchling, tadpole, and metamorph stages for 7 North American anuran species (N. Haislip et al. unpubl. data). Indeed, more research is needed investigating the relative susceptibility of amphibians during different developmental stages and why adult anurans in the UK appear to have high susceptibility.

Water temperature represents a natural environmental stressor that could impact susceptibility to ranaviruses, particularly for those species whose larvae develop during early spring or winter. Coldinduced immunosuppression has been demonstrated in several anuran species (e.g. Cooper et al. 1992, Miodoński et al. 1996) and in Notophthalmus viridescens (Raffel et al. 2006). Maniero \& Carey (1997) found that T-lymphocyte proliferation and serum complement activity were lower in Lithobates pipiens maintained at $5^{\circ} \mathrm{C}$ compared to controls held at $22^{\circ} \mathrm{C}$. They hypothesized that reduced T-lymphocyte production would cause decreased signaling of B-lymphocytes, which would reduce antibody production and compromise immunity (Maniero \& Carey 1997). Raffel et al. (2006) reported a similar trend in field-collected $N$. viridescens; fewer lymphocytes and eosinophils were detected circulating in the blood during winter and spring. Field surveillance for ranavirus supports the cold-induced immunosuppression hypothesis. We found that L. catesbeianus tadpoles collected in Tennessee were 7.7-fold more likely to be infected with FV3 in winter than in summer (Gray et al. 2007). Simi- larly, Lithobates (formerly Rana) clamitans tadpoles were 4.7-fold more likely to be infected with FV3 in autumn than in summer (Gray et al. 2007). Interestingly, Rojas et al. (2005) found that even though ATV replication in vitro was more than twice as fast at $26^{\circ} \mathrm{C}$ compared to 10 or $18^{\circ} \mathrm{C}$, mortality of larval salamanders exposed to ATV and held at the lower temperatures was at least 2.5-fold greater than that for salamanders held at $26^{\circ} \mathrm{C}$. Moreover, ATV virion titer in salamanders that died at $26^{\circ} \mathrm{C}$ was less than that for salamanders held at 10 or $18^{\circ} \mathrm{C}$ (Rojas et al. 2005), suggesting that ranavirus virulence may be greater at lower water temperatures. An important observation is that the majority of ranavirus die-offs have been reported during summer months (Collins et al. 2004, Converse \& Green 2005a,b); however, this could be a consequence of greater detection by scientists conducting fieldwork at this time, the seasonality of many amphibian populations, or factors other than water temperature stressing amphibians. Indeed, it is possible that mass mortality could occur frequently during winter in larval populations or in hibernating adults without detection. Presumably, seasonal fluctuations in temperature are less important for species with larvae that develop over short duration or at tropical latitudes. The effects of ranavirus on amphibian species without larvae are unknown.

Exposure to predators and resource limitation can induce stress in amphibian larvae, which may increase their susceptibility to ranavirus infection and morbidity. Several studies have reported that tadpoles reared with predators, competitors, or at low resource levels have higher levels of corticosterone compared with control tadpoles (Glennemeier \& Denver 2002, RotNikcevic et al. 2005). No studies have been published on the impacts of predation or competition on the susceptibility of amphibian hosts to ranaviruses. However, Hyla versicolor treated with exogenous corticosterone contracted twice the number of Alaria sp. trematode infections than control tadpoles (Belden \& Kiesecker 2005). We hypothesize that ranavirus susceptibility will increase in systems with high insect and fish predator densities. High predator densities may partly explain ranavirus emergence in summer.

Density-dependent infection and mortality associated with ranaviruses have been suggested based on field observations at die-off sites (Green et al. 2002, Brunner et al. 2004), and appears to be an important regulating mechanism in ATV-salamander systems (Greer et al. 2008). Density-dependent relationships with pathogens can occur either from competitioninduced stress or higher transmission from increased conspecific or congeneric interactions (Allen 2003, 2007). Harp \& Petranka (2006) did not detect a relationship between Lithobates sylvaticus tadpole density 
and ranavirus infection, morbidity, or mortality in a mesocosm experiment. Also, we did not find a relationship between ranavirus prevalence and tadpole density in Tennessee farm ponds (Gray et al. 2007). Controlled studies are needed to tease out the relative impact of resource limitation and contact probability on ranavirus transmission.

Other natural stressors for adult amphibians may include breeding and dispersal. Although ranaviruses usually are not as pathogenic to adults as to larvae (Gantress et al. 2003), periods of stress as an adult could cause recrudescence of chronic infection and increased virion shedding. Breeding is also a likely period of high viral transmission, as individuals aggregate at sites and direct contact among individuals is common.

\section{Anthropogenic stressors}

It is hypothesized that an increase in the number and magnitude of anthropogenic stressors in the environment are at least partly responsible for the emergence of wildlife diseases (Carey et al. 1999, Daszak et al. 2001, 2003, St-Amour et al. 2008). Amphibians may be especially susceptible to stressors in the aquatic and terrestrial environment because of their semi-permeable skin, which can uptake toxins (Boone $\&$ Bridges 2003). Inasmuch as cattle farming and fertilizers decrease water quality in wetlands through addition of nitrogenous compounds (Schmutzer et al. 2008), agricultural land use may indirectly compromise amphibian immunity and increase susceptibility to ranaviruses. Jancovich et al. (1997) published the first mass mortality from a ranavirus in North America, which occurred in salamander populations inhabiting ponds with cattle access. We found that Lithobates clamitans tadpoles in cattle-access wetlands were 3.9-fold more likely to be infected with FV3 than those in non-access wetlands (Gray et al. 2007); a potential driver in that study may have been elevated un-ionized ammonia, which was 3.2-fold greater in cattle-access wetlands compared to non-access wetlands, and at levels known to negatively influence $L$. clamitans tadpole survival (i.e. $>0.6 \mathrm{mg} \mathrm{l}^{-1}$; Jofre \& Karasov 1999). Nitrate and nitrite also may be significant anthropogenic stressors in agricultural systems (Rouse et al. 1999). In cattle systems, decreased shoreline vegetation from grazing may increase the likelihood of contracting ranaviruses. Greer \& Collins (2008) related greater ATV infection of larval salamanders in cattle-access ponds to less vegetation, which resulted in greater clustering of individuals and increased contact rates. Thus, wetlands with cattle access may be hotspots for ranavirus emergence due to a combination of reduced water quality and changes in amphibian habitat structure.

The potential effects of nitrogenous fertilizers on ranavirus susceptibility are unclear. Forson \& Storfer (2006a) exposed larval Ambystoma tigrinum to 3 concentrations of sodium nitrate $\left(0,6.8\right.$, and $\left.68 \mathrm{mg}^{-1}\right)$ and challenged them with $10^{4} \mathrm{PFU} \mathrm{ml} \mathrm{m}^{-1}$ of ATV. Leukocyte levels in the blood were significantly reduced in the 6.8 and $68 \mathrm{mg} \mathrm{l}^{-1}$ treatments, suggesting immune suppression; however, the number of infected larvae was lowest at $68 \mathrm{mg} \mathrm{l}^{-1}$. Forson \& Storfer (2006a) hypothesized that virions may have been inactivated by the high sodium nitrate concentration. Additional research is needed on the impacts of nitrogen and compound fertilizers on ranavirus viability, and their effect on amphibian immune function and susceptibility to ranaviruses.

Pesticides also negatively impact amphibian immune function and may drive ranavirus emergence. Aquatic systems can receive pesticides from direct application, terrestrial runoff, or windborne drift (Davidson et al. 2002). There is a strong pattern between recent declines in amphibian diversity at breeding sites in California and upwind agricultural pesticide application (Zabik \& Seiber 1993, Davidson et al. 2002, Davidson \& Knapp 2007) - some of these areas have experienced die-offs from ranaviruses (Green et al. 2002). Sublethal exposure of amphibians to pesticides can suppress the immune function and increase susceptibility to pathogens. For example, a pesticide mixture composed of atrazine, metribuzin, aldicarb, endosulfan, lindane, and dieldrin reduced the proliferation of lymphocytes in juvenile Lithobates pipiens, resulting in compromised immunity and increased infection by lung parasites (Rhabdias ranae; Christin et al. 2003, 2004, Gendron et al. 2003). Forson \& Storfer (2006a) reported that Ambystoma tigrinum larvae exposed to $16 \mu \mathrm{g}$ atrazine $\mathrm{l}^{-1}$ had reduced peripheral leukocyte levels and experienced increased ATV infection. However, in a companion study, Forson \& Storfer (2006b) found that atrazine at concentrations from 1.84 to $184 \mathrm{\mu g} \mathrm{l}^{-1}$ reduced infection by ATV in larval A. macrodactylum. Similar to sodium nitrate, they surmised that atrazine may have inactivated ATV, although it is unclear why this did not occur in the A. tigrinum experiment (Forson \& Storfer 2006a). Another explanation is that atrazine had an immunostimulatory effect on A. macrodactylum (Forson \& Storfer 2006b). While it appears that pesticides can affect the immune function in amphibians, more research is needed to clarify the impacts of pesticides and their degradates on ranavirus emergence. Pesticides also can change food web structure (Relyea \& Hoverman 2006, Rohr et al. 2006), which may stress amphibians and increase susceptibility. 


\section{OTHER HUMAN IMPACTS}

Habitat fragmentation can negatively impact amphibian populations through demographic and genetic isolation (Marsh \& Trenham 2001). It is hypothesized that increased occurrence of inbreeding in isolated populations will lead to loss of genetic heterozygosity, which may increase pathogen infection and morbidity rates (Altizer et al. 2003). Pearman \& Garner (2005) provided evidence that genetically isolated Rana latastei populations have a greater chance of experiencing mass mortality from ranavirus introduction. They hypothesized that increased susceptibility may have been a consequence of inbreeding depression or loss of pathogen resistance alleles from genetic drift (Pearman \& Garner 2005). Inbred Xenopus laevis tadpoles challenged with FV3 died 3-fold faster than outbred tadpoles, and inbred adults recovered from FV3 infection 2-fold slower than outbred adults (Gantress et al. 2003). These results collectively suggest that inbreeding as a consequence of genetic isolation may increase the likelihood of a ranavirus epizootic occurring. However, inbreeding as a consequence of directional selection associated with a ranavirus die-off may provide a selective advantage (Teacher et al. 2009a).

Another consequence of habitat fragmentation is increased probability of contact among infected individuals. Several studies have documented increased nestedness and elevated relative abundance of some amphibian species inhabiting breeding sites located in agricultural landscapes (Knutson et al. 1999, Kolozsvary \& Swihart 1999, Gray et al. 2004a,b). This may result from reflected movement of dispersing individuals back to breeding sites due to perceived impermeability of an anthropogenically disturbed landscape (Rothermel \& Semlitsch 2002, Gray et al. 2004b, Rittenhouse \& Semlitsch 2006). On the other hand, corridors may serve as conduits of pathogen transmission among populations (Hess 1996). The impact of ranaviruses on genetically isolated populations versus its impact on populations afforded interdemic movement needs to be determined.

Amphibian declines associated with disease have occurred in some cases at high elevation (Brem \& Lips 2008, Gahl \& Calhoun 2008). It is hypothesized that changes in ambient temperature and weather patterns from global warming, greater levels of UV-B radiation entering the atmosphere from ozone depletion, and upwind transport and deposition of pesticides may be anthropogenic stressors at high elevation sites (Davidson et al. 2002, Pounds et al. 2006, Bancroft et al. 2008, Muths et al. 2008). The relationship of ranavirus outbreaks and elevation remains unclear. Gahl \& Calhoun (2008) reported a greater occurrence of ranavirus mortality events at anuran breeding sites positioned at higher elevation, yet their sites differed by only $150 \mathrm{~m}$ in elevation. We found an inverse relationship between ranavirus prevalence and elevation among 3 sites that differed by $1070 \mathrm{~m}$ in elevation; however, the mechanisms responsible for this trend are unknown (Gray et al. 2009). More studies are needed that examine the elevational trends of ranavirus outbreaks and identify possible factors driving any relationships.

It is also possible that novel ranaviruses can be transported and introduced by humans into naïve populations, which Cunningham et al. (2003) coined pathogen pollution. We suspect that introduction of novel ranaviruses that are genetically similar to endemic types are probably the greatest risk. Several studies have demonstrated that novel ranaviruses are more pathogenic than endemic types (Majji et al. 2006, Storfer et al. 2007); however, virulence appears to be related to the genetic similarity with coevolved types and host specificity. As discussed earlier, ATV was more pathogenic to salamanders compared to anurans, and FV3 was more pathogenic to anurans than to salamanders (Schock et al. 2008). Although ranviruses appear to be widespread, it is possible that some populations lack evolutionary exposure. In the case of completely naïve populations, the pathogenicity of ranaviruses remains unknown.

Ranaviruses could be transported among watersheds by recreationists, farmers, and researchers. Transport could occur on fomites such as boots, fishing and research gear, farm equipment, and boats. Fisherman and bait industries also transport infected amphibians across watersheds. Frequently, trout (subfamily Salmoninae) fishermen in the Appalachian Mountains of eastern North America use adult plethodontid salamanders for bait (Copeland et al. 2009), and, in the southwestern USA, largemouth bass Micropterus salmoides fishermen use larval Ambystoma tigrinum as bait (Picco et al. 2007). The Canadian Ministry of Natural Resources (CMNR) allows use of Lithobates pipiens for fishing (CMNR 2009), which is a known carrier of ranavirus (Greer et al. 2005). Jancovich et al. (2005) provided molecular evidence for the high genetic variability among ATV isolates in the western USA, and hypothesized that a mechanism for this variability may be the interstate transport of salamanders for fishing bait. Picco et al. (2007) reported that $85 \%$ of bait shops in Arizona contained ATV-positive salamanders. Transportation of live amphibians also occurs among countries for pet trade, food, and traditional medicines (Schlaepfer et al. 2005). In 3 major ports of entry in the USA, 4.66 million live frogs on average are imported annually, with $8.5 \%$ infected with ranavirus (Schloegel et al. 2009). Importation of ranavirusinfected frogs is a concern if these animals enter the pet trade, aquaculture, or bait fish industries, which 
many of them do (Schloegel et al. 2009). Thus, novel ranaviruses could be introduced by humans into naïve populations by transporting contaminated water or fomites, using infected individuals for fish bait, or releasing non-native amphibians.

\section{PATHOLOGY AND DIAGNOSTICS}

Accurate diagnosis of amphibian diseases requires an understanding of gross and histopathological signs. Molecular techniques are also available to assist in diagnosis. Below we summarize what is known about the pathology and diagnostics of ranaviral disease in amphibians. We also discuss how quickly ranaviral disease can progress in infected amphibians, and provide direction on surveillance of ranaviruses in populations.

\section{Field signs and gross lesions}

Field signs (e.g. lordosis, erratic swimming, lethargy) and gross lesions (e.g. swelling, erythema) indicative of ranavirus infection depend on amphibian developmental stage. Tweedell \& Granoff (1968) reported loss of pigmentation, lordosis, epithelial sloughing, and petechiation in Lithobates pipiens embryos. For subclinical infections (i.e. infection, but no apparent disease), no field signs or gross lesions are generally observed (Miller et al. 2009). However, in sublethal infections (i.e. morbidity, but not mortality), field signs and gross changes are usually apparent, but the severity depends on the extent of disease. Morbid amphibian larvae often display erratic swimming, lethargy, and lack of equilibrium (Jancovich et al. 1997, Bollinger et al. 1999, Docherty et al. 2003, Converse \& Green 2005a). Gross lesions in larvae include erythema at the base of the gills, ventrum, and legs, and swelling of the legs, body, and gular region (Fig. 3; Jancovich et al. 1997, Bollinger et al. 1999, Docherty et al. 2003, Converse \& Green 2005a). Cutaneous polyps also have been reported in Ambystoma tigrinum larvae (Jancovich et al. 1997, Bollinger et al. 1999). In adults, erythema of the legs and ventrum, ulceration of the skin, and erythema near the vent or plantar surfaces of the feet have been reported (Fig. 3; Cunningham et al. 1996, Converse \& Green 2005a, Miller et al. 2008). In fatal cases of larvae and adults, intracoelomic lesions may be present, and include petechial or ecchymotic hemorrhages of the internal organs (especially the mesonephros [kidneys], reproductive organs, and liver) and pale swollen livers (Cunningham et al. 1996, Docherty et al. 2003, Miller et al. 2007, 2008). Additionally, the gastrointestinal tract may be empty and the gall bladder may be enlarged, both of which are consistent with anorexia.
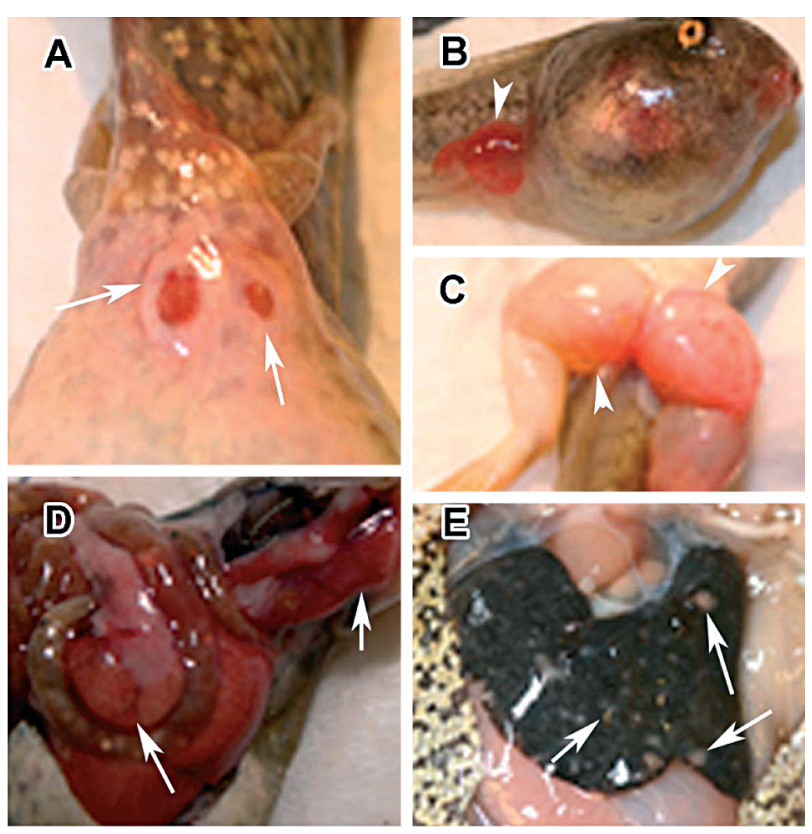

Fig. 3. Gross lesions observed in clinical (sublethal and lethal) infections with Ranavirus. (A) Ulceration (arrows) and hemorrhage of the skin in a Lithobates catesbeianus tadpole. (B) Red (hemorrhagic) legs (arrowhead) in a Hyla chrysoscelis tadpole. (C) Swollen red legs (arrowheads) in a L. catesbeianus tadpole. (D) Irregular areas of erythema (arrows) on the serosa of internal organs in a L. catesbeianus tadpole. (E) Variably sized tan foci (arrows) on the liver of an adult Theloderma corticale that represent areas of necrosis when viewed in histological sections

\section{Histological lesions}

Similar to gross changes, histological changes may be minimal or absent in subclinically infected individuals. We found non-specific histological changes (i.e. minimal to mild lymphocytolysis, lymphoid depletion, and mild vacuolation of hepatocytes and renal tubular epithelium) in ranavirus-positive Lithobates catesbeianus and L. clamitans tadpoles collected from farm ponds in Tennessee (Gray et al. 2007, Miller et al. 2009). Non-specific changes may be due to various endogenous or exogenous challenges to the host, such as steroid release secondary to stress, antigen exposure, and systemic illness. Although changes may be non-specific even in fatal cases (Driskell et al. 2009), extensive organ necrosis may be observed in both larvae and adults, with the liver, spleen, kidney, and intestines most affected (Fig. 4A; Bollinger et al. 1999, Gantress et al. 2003, Robert et al. 2005, Converse \& Green 2005a, Miller et al. 2007, 2008). The renal tubular epithelium can be attenuated, with various degrees of vacuolation and necrosis in more severely affected cells (Gantress et al. 2003, Converse \& Green 2005a, Miller et al. 2008). Skeletal muscle degenera- 

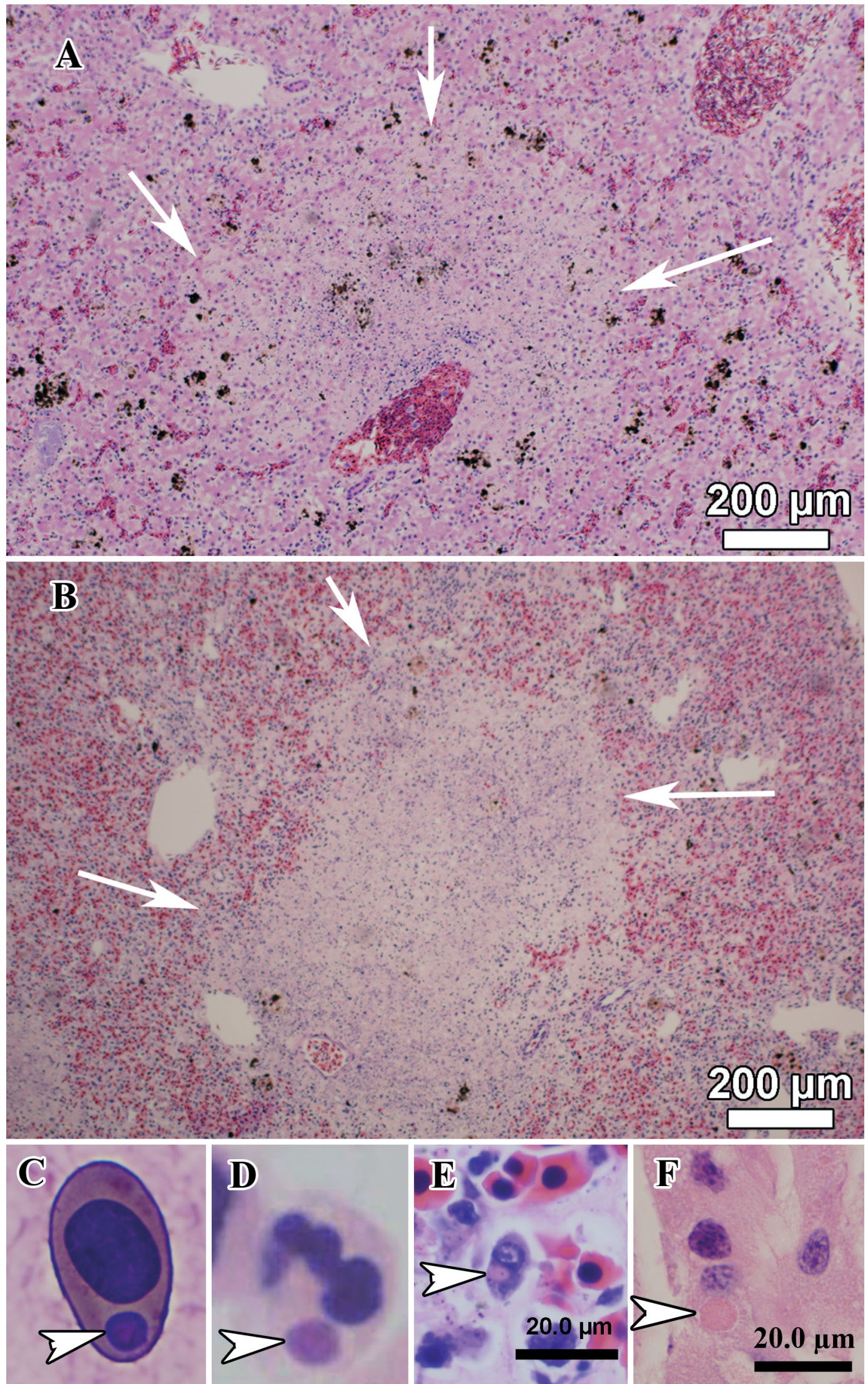

$20.0 \mu \mathrm{m}$ 
tion has been reported in adults only, but likely also occurs in larvae and is characterized by areas of myofiber disarray, fragmentation, and loss of crossstriations (Miller et al. 2008). Intracytoplasmic inclusions may be found in various cell types, including erythrocytes, macrophages, lymphocytes, leukocytes, hepatocytes, epithelial cells, and fibroblasts (Fig. 4B; Cunningham et al. 1996, 2008, Jancovich et al. 1997, Gantress et al. 2003, Converse \& Green 2005a, Green \& Converse 2005, Miller et al. 2007, 2008). Cunningham et al. (1996) described basophilic inclusions and acidophilic inclusions, with the latter surrounded by a clear halo. They found that basophilic inclusions contained iridovirus-like particles occasionally surrounded by rough endoplasmic reticulum (RER), whereas the acidophilic inclusions were composed of whorls of RER surrounding undefined central cores. Cunningham et al. (1996) surmised that both inclusions are likely due to the presence of iridovirus-like particles. Additionally, Docherty et al. (2003) reported necrosis and viral inclusions in the brain (meninges), gills, nasal tissue (neuroepithelium), adipose tissue, trachea, muscle, and bone (inclusions presumed to be in osteoclasts). Finally, Jancovich et al. (1997) described intranuclear inclusions in the cells of the epidermis, gills, and liver in terminal stages of disease in Ambystoma tigrinum. Often bacterial incursion of organs has been observed, but is presumed to be due to secondary or opportunistic invasion (Cunningham et al. 1996, Miller et al. 2007, 2008).

\section{Time to death}

The amount of time to mortality from amphibian ranaviruses depends on the route of transmission and host characteristics. Although unrealistic in nature, intraperitoneal (IP) injection of ranaviruses induces gross signs of infection in larval salamanders and tadpoles within only a few days, and death can occur in $<1$ wk (e.g. Wolf et al. 1968, Jancovich et al. 1997). For postmetamorphic frogs, time to mortality can be longer, but depends on species and age. Subcutaneous, IP, and intravenous injection of ranavirus in adult Rana temporaria caused mortality in roughly $2 \mathrm{wk}$ (Cunningham et al. 2007a), but typically occurred faster (6 to $17 \mathrm{~d}$ ) in adult Anaxyrus (formally Bufo) americanus and A. fowleri (Wolf et al. 1968). In the genera Anaxyrus and Scaphiopus juveniles died within 5 to $7 \mathrm{~d}$ following IP injection (Wolf et al. 1968). Thus, injection of ranavirus into amphibians is an effective route to induce ranaviral disease albeit unnaturally.

Ingestion of infected tissue or oral inoculation of ranavirus also results in rapid morbidity (Wolf et al. 1968). Lithobates sylvaticus and Rana latastei tadpoles that were allowed to scavenge ranavirus-infected tadpole carcasses began dying after only a few days, and $>90 \%$ were dead within 5 and 12 d, respectively (Pearman et al. 2004, Harp \& Petranka 2006). We found L. palustris and Hyla chrysoscelis tadpoles that were orally inoculated with $10^{6}$ PFU of FV3 began dying in $4 \mathrm{~d}$, and $>95 \%$ mortality occurred in $8 \mathrm{~d}$ (authors' unpubl. data); in that study, gross signs of ranavirus infection were observed in approximately $90 \%$ of morbid tadpoles, typically appearing 1 to $7 \mathrm{~d}$ before mortality (authors' unpubl. data).

In contrast, time to morbidity and death when exposed to ranaviruses in water is more variable. Lithobates sylvaticus and Rana latastei tadpoles exposed to ranavirus-infected carcasses, but not allowed to scavenge them, began dying after 4 and $6 \mathrm{~d}$, and $>75 \%$ were dead between 6 and 20 d, respectively (Pearman et al. 2004, Harp \& Petranka 2006). Similarly, R. latastei tadpoles exposed to 1 of 5 doses of FV3 $\left(4.3 \times 10^{2}\right.$ to $4.3 \times 10^{6} \mathrm{PFU} \mathrm{ml} \mathrm{m}^{-1}$ ) in a water bath for $24 \mathrm{~h}$ began dying in 2 to $5 \mathrm{~d}$, and $100 \%$ were dead by $12 \mathrm{~d}$ (Pearman et al. 2004). Water bath exposure of adult $R$. temporaria to ranavirus took roughly $20 \mathrm{~d}$ to cause mortality, but the likelihood of death was related to the type of ranavirus (Cunningham et al. 2007a). In comparison to the ranids, Brunner et al. (2005) found that larval salamanders exposed for $1 \mathrm{wk}$ to a water bath containing 1 of 6 doses $\left(10^{2}\right.$ to $\left.10^{5} \mathrm{PFU} \mathrm{m \textrm {m } ^ { - 1 }}\right)$ of ATV developed gross signs of disease in 10 to $25 \mathrm{~d}$ and died an average of $10 \mathrm{~d}$ later. They found that the odds of mortality for salamanders with signs of infection were 20-fold greater than for individuals with no signs of infection (Brunner et al. 2005). In their study, only $5 \%$ of the salamanders that died did not have gross signs of infection, and only $11 \%$ of the apparently normal indi-

Fig. 4. (A,B) Photomicrographs of hematoxylin and eosin-stained sections of liver (A) and spleen (B), showing organ necrosis (arrows) observed in terminal stages of Ranavirus infection in a recently metamorphosed Lithobates catesbeianus. (C) Wrights and Giemsa-stained blood smear from a ranavirus-positive adult Eurycea wilderae, showing an intracytoplasmic inclusion (arrowhead), which cannot be distinguished from those of erythrocytic iridovirus. (D) Hematoxylin and eosin-stained muscle from a ranavirus-positive Notophthalmus viridescens, showing a non-granular leukocyte (e.g. neutrophil) with an intracytoplasmic inclusion body (arrowhead). (E) Hematoxylin and eosin-stained spleen of a recently metamorphed ranavirus-positive L. catesbeianus, showing an intracytoplasmic inclusion (arrowhead) within a mononuclear cell. (F) Hematoxylin and eosin-stained renal tubule of a ranavirus-positive $L$. catesbeianus tadpole, showing an intracytoplasmic inclusion (arrowhead) that is surrounded by a clear halo within an epithelial cell 
viduals tested positive for the ranavirus (Brunner et al. 2005). Collectively, these results suggest that ranavirus-associated morbidity can occur within days of virion exposure in water, but time to mortality is dependent on developmental stage, and ranaviral disease in salamanders appears to progress slower than in anurans.

\section{Diagnostics}

In general, several tests are necessary to differentiate between ranavirus infection and disease. Useful diagnostic tools for characterizing ranaviruses include histology, cytology, virus isolation, electron microscopy, and molecular modalities (i.e. PCR, RFLP, sodium dodecyl sulfate polyacrylamide gel electrophoresis [SDS-PAGE]). Most of these tests can be performed on dead or living organisms, but the time between death and the postmortem examination should be minimized. Although formalin-fixed specimens are preferred for histological examination, ethanol-fixed specimens may be used, but prolonged storage in ethanol can dry tissues and decrease their usefulness for histology (Green et al. 2009). For PCR, fresh or frozen tissues are preferred, but ethanol-fixed specimens also can be used. Although formalin fixation can damage DNA, Kattenbelt et al. (2000) demonstrated that Ranavirus DNA can be successfully extracted from formalin-fixed tissues. Thus, formalinfixed-paraffin-embedded tissues can be used in PCR assays for ranavirus testing and make it possible to conduct retrospective studies (Cullen \& Owens 2002, Miller et al. 2008, Driskell et al. 2009). Fresh or frozen tissues are necessary for virus isolation and culture, because viable virus is necessary. Finally, collection of whole blood is useful for inspection of ranavirus inclusion bodies in erythrocytes and leukocytes (Converse \& Green 2005a, Green \& Converse 2005, Miller et al. 2007), but it is important to note that viral inclusions found only in erythrocytes may represent erythrocytic iridoviruses - the pathogenicity of which remains uncertain (Green \& Converse 2005). Although many species or age classes of amphibians are too small to collect substantial amounts of blood, usually enough blood can be collected to make a blood smear. Blood may be collected antemortem from the ventral vein in adults or tail vein in salamanders, or collected postmortem from the heart of larval or adult amphibians (Wright 2001).

Virus isolation may be used to test for the presence of viable virus and aids in characterizing the virus type, but it cannot be used to diagnose the presence of disease. Cultured virus is used to perform some molecular tests such as SDS-PAGE and RFLP. Cultured virus can also yield better products for sequencing. Currently, ranaviruses are cultured on a variety of fish cell lines (e.g. fathead minnow epithelioma papilloma cyprini cells); however, amphibian cell lines are becoming increasingly available. It is possible that culturing may be optimized when amphibian cell lines are used, but this remains to be tested. One caveat is that virus isolation is often unsuccessful (Cullen \& Owens 2002), with success being dependent upon a variety of factors, including degree of postmortem autolysis, tissue type, and the ability to optimize the incubation conditions (e.g. temperature) for a specific ranavirus. Thus, infection cannot be ruled out based solely on negative isolation results (Cullen \& Owens 2002).

Electron microscopy is used for confirmation of cultured virus, and detection of virions within fixed and paraffin-embedded tissues (Gray et al. 2007, Burton et al. 2008, Miller et al. 2009). However, electron microscopy is only reliable for identification to the family level (Iridoviridae); it cannot be used to definitively verify a ranavirus. Thus, other methods (e.g. PCR and sequencing) are necessary to further classify iridoviruses.

Molecular testing for ranaviruses can be performed on fresh, fixed, or paraffin-embedded tissues, as well as on blood (Green et al. 2009). Although used infrequently, amphibian feces or swabs of the oral cavity, cloaca, and skin lesions can be useful non-lethal methods for diagnostic testing (Driskell et al. 2009, Gray et al. 2009), and may provide evidence of viral shedding. For PCR testing, one caveat is that a positive PCR result only confirms the presence of virions (non-viable or viable). Thus, it is important to perform supportive tests (e.g. histological examination) to differentiate between ranavirus infection (i.e. presence of the pathogen within the animal) versus disease (i.e. negatively impacting health such as cellular degeneration and necrosis). Also, false-negative and -positive results are possible, which is discussed in the section 'Surveillance' that follows. Although conventional PCR has been routinely used for Ranavirus testing and is necessary for sequencing PCR products, real-time quantitative PCR (qPCR) can be used to quantitate viral load (Yuan et al. 2006, Storfer et al. 2007). Viral load is quantified by standardizing the amount of genomic DNA across samples. Although the correlation between viral load and ranaviral disease remains unclear, we have found that viral load and mortality rates are positively correlated (authors' unpubl. data). It is important to note that the brightness of conventional PCR bands does not equate to viral load even if genomic DNA is standardized. Further, several studies have reported that qPCR may be more sensitive than conventional PCR at detecting virus infection (Brunner et al. 2005, Pallister et al. 2007, Driskell et al. 2009). 
Currently, RFLPs, protein profiles, and sequence analysis of the MCP gene are used most often to identify unique types of Iridoviridae (Williams et al. 2005, Majji et al. 2006, Schock et al. 2008). Given the conservative nature of the $\mathrm{MCP}$, this portion of the Ranavirus genome may not be ideal to separate Ranavirus types. Ridenhour \& Storfer (2008) provide an alternative approach to MCP analysis for differentiating ranaviruses that uses multiple DNA sequences from the entire genome and Bayesian- and maximum-likelihood-based analysis. Holopainen et al. (2009) also provide a novel approach to differentiate ranaviruses using PCR and restriction enzyme analysis of DNA polymerase and a neurofilament triplet H1-like protein gene. As stated earlier, sequence analysis based solely on a 500 bp region of the MCP is insufficient to classify an iridovirus as a Ranavirus species.

Histological examination is the best method to confirm the presence of disease versus infection. Specifically, the extent to which organs are affected by ranavirus can be determined by histological examination only, and changes due to opportunistic or concurrent pathogens can be assessed (Miller et al. 2008). Techniques such as immunohistochemical staining (IHC) and electron microscopy can be applied to histological sections and allow identification of ranavirus in specific cells (Cunningham et al. 1996, 2008, Burton et al. 2008, Balseiro et al. 2009). Negative aspects of histology include the requirement of lethal collection and cost. Generally, lethal collections are not possible for investigations with imperiled species. Costs for preparing slides for histological examination can be high, especially if serial sectioning of the tissues is needed, which can be important to gain a representative view of all organs. At this time, commercially available antibodies for IHC are not available for ranavirus, reducing the applicability for most researchers. Also, many laboratories do not have electron microscopes, due to the initial cost and maintenance of this equipment. Thus, we recommend that teams of researchers work together to apply as many diagnostic methods as possible for investigations of surveillance as well as morbidity and mortality events.

\section{Surveillance}

Pathogen surveillance is fundamental to disease monitoring. We are unaware of any active widespread ranavirus surveillance programs, although in the USA, the Tennessee Wildlife Resources Agency is currently supporting an initial sampling effort ( $\mathrm{n}=40$ locations) across 2 physiographic regions (Cumberland Plateau and Tennessee River Ridge and Valley). Through the project RANA, the European Commission is develop- ing the framework necessary for future surveillance of ranaviruses (European Commission 2009). Also, in the UK, the non-profit Amphibian and Reptile Conservation Trust (www.arc-trust.org/) assists in reporting dieoffs from ranaviruses and other causes. We encourage other natural resource organizations and nations to consider similar programs for monitoring ranaviruses and other amphibian pathogens. Surveillance is important to detect epizootics and build an understanding of how pathogen prevalence varies between disturbed and undisturbed sites and among amphibian species. Surveillance also can be used to direct conservation strategies in areas with high prevalence to minimize the likelihood of a die-off.

Four techniques have been used to test for ranaviruses: whole organism, internal organs, tail or toe clips, and skin swabs (Gray et al. 2007, 2009, Greer \& Collins 2007, St-Amour \& Lesbarrères 2007). We recommend testing for ranaviruses from internal organs (especially liver and kidney), because they are more likely to provide evidence of systemic infection as opposed to tail or toe clips and swabs (i.e. external surfaces), which may simply represent surface exposure to the virus. Whole-organism testing via grinding amphibians using a laboratory-grade tissue blender (e.g. Stomacher 80; Greer \& Collins 2007) includes internal organs, but also virions potentially from the environment. In a pilot study with Lithobates catesbeianus larvae, we determined that tail clips had a $20 \%$ false-negative and $6 \%$ false-positive rate for systemic infection (i.e. when compared to test results from internal organs; authors' unpubl. data); skin swabs had a $22 \%$ false-negative and $12 \%$ false-positive rate for systemic infection in that study. Thus, when lethal organism collection is not feasible or allowed, we recommend testing tail clips over skin swabs for ranaviruses. Greer \& Collins (2007) also found that tail clips from postmetamorphic salamanders resulted in false negatives, but this effect was dependent on postinfection duration. Fourteen days postinfection, tail clip and whole-organism tests were identical (Greer \& Collins 2007). St-Amour \& Lesbarrères (2007) reported a $3 \%$ false-negative rate from toe clips. Animals that are collected for ranavirus testing should be euthanized and either stored at $-80^{\circ} \mathrm{C}$ or preserved in $95 \% \mathrm{EtOH}$. Samples should remain frozen until laboratory testing, as multiple cycles of freezing and thawing can affect test accuracy.

\section{RANAVIRUS EMERGENCE}

An emerging pathogen is defined as one that causes disease and has recently increased in prevalence or geographic range, been isolated from a new host, or is 
genetically distinct from other known pathogen species (Daszak et al. 2000). Inasmuch as the majority of reported die-offs associated with ranaviruses have occurred since the mid-1990s (Green et al. 2002, Muths et al. 2006, Cunningham et al. 2007b), it appears that this pathogen is emerging. However, an increase in the number of diagnoses identifying ranaviruses as an etiologic agent may be a consequence of greater surveillance and advancements in molecular techniques for virus detection (Williams et al. 2005). Thus, scientists must exercise caution in concluding disease emergence based on surveillance data alone. We suggest that at least 2 of the above criteria be used as evidence of ranavirus emergence.

Emerging pathogens can be novel or endemic (Rachowicz et al. 2005). Novel emerging pathogens typically result from the introduction of new Ranavirus types, and endemic emerging pathogens are usually a consequence of the decreased host immune function associated with stressors (Carey et al. 2003a, Rachowicz et al. 2005). Where evidence exists that ranaviruses are emerging, either scenario is possible (see previous sections 'Anthropogenic stressors' and 'Other human impacts'), which can be determined through phylogenic concordance analysis (Storfer et al. 2007). This analysis compares concordance of host and pathogen phylogenies through simulations and maximum-likelihood estimation (Farris et al. 1995, Shimodaira \& Hasegawa 1999, Goldman et al. 2000). Storfer et al. (2007) used this analysis and provided evidence that ATV was novel in 3 salamander populations, yet endemic in 8 populations located across western North America. It is reasonable to surmise that ranavirus emergence is not a consequence of virus evolution, because this pathogen can infect multiple host species and sections of the genome are conserved (Chinchar et al. 2009). However, considerable genetic variability of ATV isolates and genetic evidence of host switches provides support that rapid evolution of ranaviruses is possible (Jancovich et al. 2005, Storfer et al. 2007, Ridenhour \& Storfer 2008, Schock et al. 2008).

\section{CONSERVATION}

\section{Threat of ranaviruses to amphibian species survival}

Epidemic disease models predict that pathogens cannot directly cause local population extinction if transmission is density dependent, because as individuals die, host density drops below a threshold for efficient transmission (Anderson \& May 1979). However, empirical evidence of thresholds for wildlife diseases is rare (Lloyd-Smith et al. 2005a). Presence of reservoirs, high environmental persistence of pathogens, and fre- quency-dependent transmission can increase the likelihood of disease-induced extinction (Woodroffe 1999, de Castro \& Bolker 2005). All of these characteristics are possible in ranavirus-host systems. Duffus et al. (2008) provided evidence of ranavirus reservoirs and frequency-dependent transmission in an amphibian community with known annual die-offs. Long environmental persistence of ranavirus virions is also possible (Langdon 1989). However, this model is not accurate for all amphibian systems. For example, there are few ranavirus reservoirs, environmental persistence of virions is low, and density-dependent transmission is likely in ATV-salamander systems (Greer et al. 2008). Thus, the likelihood of local extirpation of a species from ranaviruses is dependent on the amphibian community and the characteristics of their habitat that contribute to persistence and transmission of virions.

Several studies have reported population declines in amphibian species following ranavirus epizootics (e.g. Collins et al. 1988, Cunningham et al. 1996, Greer et al. 2005, Schock \& Bollinger 2005, Teacher 2008, Ariel et al. 2009). Local population declines or extirpations can have rippling effects that increase the possibility of metapopulation or species extinction (Hanski 1999). Superspreading events may also occur with ranaviruses from a few highly infectious individuals or in populations exposed to anthropogenic stressors (Lloyd-Smith et al. 2005b). The intricacies of ranavirusdisease dynamics remain to be determined, and likely include a complex interaction of reservoir species, transmission routes, virion persistence, stressors, and host immunity (Fig. 1). However, enough evidence exists to conclude that ranaviruses are a significant pathogen driving local population dynamics in some areas and resulting in at least localized die-offs of amphibians.

\section{Possible strategies}

Very few studies have been conducted on the use of conservation strategies to reduce disease emergence; however, the lack of this research should not preclude scientists from making logical recommendations. Simple strategies can be implemented if factors that cause emergence are understood. Although ranaviruses may emerge in a population due to natural stressors or virion shedding by native species, emergence also can occur as a result of human activity. Most often, humaninduced emergence is related to immune suppression from anthropogenic stressors or the introduction of novel virus types. Thus, strategies that reduce anthropogenic stressors or the chance of pathogen pollution should reduce the likelihood of human-induced ranavirus emergence. 
Establishing undisturbed vegetation buffers around amphibian breeding sites has been recommended to minimize human impacts on the aquatic environment (Semlitsch \& Bodie 2003). Semlitsch \& Bodie (2003) recommended at least $30 \mathrm{~m}$ of vegetation to buffer the aquatic environment. We documented that excluding cattle from wetlands with electric fencing reduced ranavirus prevalence in some amphibian species (Gray et al. 2007). For that study (op. cit.), cattle were fenced from 20 to $200 \mathrm{~m}$ from amphibian breeding sites; thus, a $20 \mathrm{~m}$ buffer may be sufficient to reduce cattle effects and ranavirus emergence. Prudent agricultural practices such as restricting chemical applications to calm days and ensuring that aircraft-applied pesticides are not released over amphibian breeding sites would reduce the potential effects of chemicals on ranavirus emergence.

Conservation strategies also could be implemented to reduce the likelihood of pathogen pollution. Given that larval and adult amphibians can be sublethally infected with ranaviruses (Brunner et al. 2004, Gray et al. 2007, Picco et al. 2007, Greer et al. 2009), transportation of amphibians among watersheds should be regulated to reduce novel ranavirus introduction. Many states in the USA and many Canadian provinces allow use of amphibians as bait for fishing (Picco \& Collins 2008, CMNR 2009). In Tennessee, use of amphibians for fishing is restricted to the watershed where they were captured. We encourage similar or more stringent regulations in states or nations without restrictions, and recommend that regional transport of live amphibians be accompanied with certification of Ranavirus-negative test results. We also discourage the commercial sale of amphibians for fish bait. Storfer et al. (2007) demonstrated that an ATV type isolated from larval Ambystoma tigrinum in a bait shop was more virulent than wild types. For amphibians traded internationally, Gray et al. (2007) suggested that mandatory testing for ranaviruses be considered an exportation requirement. Recognizing that ranaviruses are associated with mass mortality of amphibians and that this pathogen can be transported in sublethally infected individuals (Schloegel et al. 2009), the World Organization for Animal Health (OIE, www.oie.int/ eng/en_index.htm) recently listed ranaviral disease as a notifiable disease. Guidelines have been established by the OIE for testing amphibians prior to international shipment and for declaration of ranavirus-free animals. The OIE also is in the process of preparing guidelines for diagnostic testing of amphibians for ranaviruses.

Given the potentially long duration of environmental persistence for ranavirus virions (Langdon 1989), disinfecting equipment that contacts water or soil where amphibians live should be performed. Langdon (1989) demonstrated that $70 \% \mathrm{EtOH}$ was effective in inacti- vating FV3. Bryan et al. (2009) found that solutions of $3 \%$ bleach or $0.75 \%$ Nolvasan $(2 \%$ chlorhexidine diacetate; Fort Dodge Animal Health) applied for $1 \mathrm{~min}$ were effective in inactivating ranaviruses. Although disinfecting equipment may be impractical for the public, scientists working in aquatic environments should follow this practice (Green et al. 2009). Natural resource agencies should consider developing educational websites and public outreach brochures on the benefits of disinfecting equipment and recreational gear that comes in contact with water to control diseases in amphibians and other aquatic vertebrates. Examples of outreach education sheets on herpetofaunal diseases, collecting and shipping protocols for morbid or dead amphibians, and disinfecting procedures are available on the Southeast Partners in Amphibian and Reptile Conservation website (www.separc.org).

\section{RESEARCH DIRECTIONS}

Much remains to be learned about the genetics, evolution, and ecology of amphibian ranaviruses, and how stressors interact to impact the emergence of this pathogen. Research directions in Ranavirus genetics have been reviewed by Williams et al. (2005), but include using knock-down and knock-out technology to determine gene functions (Xie et al. 2005, Sample et al. 2007). Advances in the genomics of Ranavirus can be used to develop vaccines and control transmission in captive facilities (Nakajima et al. 2002, Williams et al. 2005, Caipang et al. 2006).

Evidence exists that Ranavirus types can infect multiple hosts, but susceptibility varies among amphibian species (Storfer et al. 2007, Schock et al. 2008). Studies are needed that determine species-specific susceptibility to different Ranavirus types across geographic regions. This information is fundamental to understanding which amphibian species are most at risk of ranavirus epizootics. It also is important to investigate the extent of ranavirus emergence and the prevalence of endemic and novel viral types. Largescale surveillance programs are needed to identify areas of ranavirus emergence. The occurrence of novel and endemic types can be determined by comparing viral and host phylogenies. Storfer et al. (2007) provided a good example of using phylogenetic concordance analyses to accomplish this task for ATV and Ambystoma tigrinum. Similar studies are needed for other amphibians and Ranavirus species. These advances will help in identifying the mechanism of ranavirus emergence (i.e. pathogen pollution or stressors; Storfer et al. 2007).

Although several studies have been performed on the ecology of ranaviruses (e.g. Brunner et al. 2004, 
2007, Pearman et al. 2004, Duffus et al. 2008), our understanding of how this pathogen infects amphibians and is maintained in the environment remains limited. Studies are needed on the environmental persistence of ranaviruses in water, soil, and decaying tissue, and on fomites. Vertical transmission has been hypothesized by several investigators (Greer et al. 2005, Harp \& Petranka 2006, Duffus et al. 2008); however, a study that controls for in vitro contamination has not been performed. We know that metamorphs are highly susceptible to ranaviruses followed by larvae and adults in some cases (Gantress et al. 2003, Brunner et al. 2004); however, we do not completely understand the pathogencity of ranaviruses during early developmental stages. Studies are needed that test for the effects of ranaviruses on embryos and hatchlings and that compare infection, recovery, and mortality rates among pre- and pro-metamorphosis larvae, metamorphs, and adults (Fig. 1A). Further exploration is needed into the high susceptibility of adult amphibians in the UK. Additional controlled studies are needed to test the susceptibility of native and introduced reptiles and fish to Ranavirus types isolated from amphibians to identify the likelihood of viral maintenance in other ectothermic reservoirs (Moody \& Owens 1994, Ariel 1997, Ariel \& Owens 1997). These advances are important to determine how ranaviruses are maintained in the environment and to identify the most susceptible stages in amphibian development.

Only a few studies have been conducted on the role of stressors in ranavirus emergence (Forson \& Storfer 2006a,b, Gray et al. 2007). It appears some agricultural chemicals have immunosuppressive effects on certain amphibians that could lead to increased susceptibility to ranavirus infection (Forson \& Storfer 2006a). However, only 2 pesticides (atrazine and carbaryl) and 1 fertilizer (sodium nitrate) have been studied and only for 2 amphibian species (Forson \& Storfer 2006a,b, A. Storfer, Washington State University, unpubl. data). Future studies need to include a cadre of pesticides, fertilizers, and mixtures of chemicals with $>1$ amphibian species (e.g. Relyea 2004, Hayes et al. 2006) to fully understand the effects of these possible stressors on ranavirus dynamics in amphibian communities. Also, no studies have been conducted on the effects of heavy metals and acidification. Studies on anthropogenic stressors should be crossed with natural stressors, such as water temperature, food limitation, and presence of a predator to better understand the impact of ranaviruses within communities. Factors associated with elevation (e.g. increased UV-B radiation, temperature) also need to be investigated (Gahl \& Calhoun 2008).

Concurrent infections of ranaviruses with other amphibian pathogens have been documented (e.g.
Cunningham et al. 1996, Bollinger et al. 1999, Fox et al. 2006, Schmutzer 2007, Miller et al. 2008). However, to date, only 1 controlled study has been published on how ranavirus interacts with other pathogens to induce morbidity (Cunningham et al. 2007a). It is hypothesized that primary infection by one pathogen will lead to secondary infection by other pathogens; however, this has never been tested via ordered experimental challenges. Possible significant amphibian pathogens include other ranaviruses, Batrachochytrium dendrobatidis, Aeromonas hydrophila, helminthic and myxozoan parasites, Saprolegnia sp., and Perkinsus-like agents (Green \& Converse 2005, Converse \& Green 2005a,b, Davis et al. 2007, Romansic et al. 2007, Rohr et al. 2008). Selection of pathogens should correspond to the likelihood of co-occurrence in the wild, which is possible for most of these pathogens. Co-infection studies are fundamental to understanding the significance of pathogens as primary or secondary invaders and to assigning pathogen risk levels. Identification of primary pathogens can help direct intervention strategies that minimize their effects in amphibian communities.

Most of the controlled ecological experiments performed on amphibian ranaviruses have been with ATV and Ambystoma trigrium. Although ATV and A. tigrinum are a good model to explore host-pathogen dynamics (Collins et al. 2004), variations in host responses likely exist for other ranaviruses and amphibian species. To date, no controlled studies have been conducted on plethodontid salamanders - the most diverse family of urodeles (Gray et al. 2009). Moreover, global anuran species richness is approximately 10fold that of urodeles, yet only a handful of controlled ecological studies exist. We also encourage scientists to study other ranavirus species, particularly FV3 given its global distribution in wild and captive populations (Zupanovic et al. 1998, Zhang et al. 2001, Greer et al. 2005, Fox et al. 2006, Cunningham et al. 2007b, Gray et al. 2007, Miller et al. 2007, Pasmans et al. 2008, Schock et al. 2008).

It remains unclear whether amphibian ranaviruses are capable of causing extinction (Greer et al. 2009). This lack of understanding is a consequence of infrequent surveillance for this pathogen in common and uncommon species in an amphibian community. Given that amphibian ranaviruses can infect multiple species in a community, extirpation of uncommon susceptible species is most likely. Annual broad-scale surveillance coupled with population monitoring is needed to determine if amphibian ranaviruses are contributing to global amphibian declines. We strongly encourage government agencies and conservation organizations to develop annual monitoring sites for ranaviruses. The prevalence of Ranavirus should be estimated, and, when possible, the histopathological changes in tissues 
examined, especially during a die-off. We also recommend simultaneous testing for Batrachochytrium dendrobatidis, due to its role in amphibian declines in many parts of the world. Through broad-scale surveillance and controlled experiments, we will develop a greater understanding of the ecology and pathology of amphibian ranaviruses and factors that may contribute to emergence.

Acknowledgements. Funds for our research on ranaviruses have been provided by the University of Tennessee Institute of Agriculture, East Tennessee Research and Education Center, University of Georgia Veterinary Diagnostic and Investigational Laboratory, Tennessee Wildlife Resources Agency, and the Association of Reptilian and Amphibian Veterinarians. M.J.G. and J.T.H. are supported by the University of Tennessee Center for Wildlife Health located in the Department of Forestry, Wildlife and Fisheries, and D.L.M. is supported by the University of Georgia College of Veterinary Medicine. We thank M. Berrill, J. L. Brunner, V. G. Chinchar, and 3 anonymous referees for reviewing initial drafts of our manuscript. We also acknowledge A. Teacher, A. Duffus, and A. Cunningham for providing insight into die-offs in the UK.

\section{LITERATURE CITED}

Alford RA (1999) Ecology: resource use, competition and predation. In: McDiarmid RW, Altig R (eds) Tadpoles: the biology of anuran larvae. University of Chicago Press, Chicago, IL, p 240-278

Allen LJS (2003) An introduction to mathematical biology. Prentice Hall, Upper Saddle River, NJ

Allen LJS (2007) An introduction to stochastic processes with applications to biology. Prentice Hall, Upper Saddle River, NJ

> Allender MC, Fry MM, Irizarry AR, Craig L, Johnson AJ, Jones M (2006) Intracytoplasmic inclusions in circulating leukocytes from an eastern box turtle (Terrapene carolina carolina) with iridoviral infection. J Wildl Dis 42:677-684

Altizer S, Harvell D, Friedle E (2003) Rapid evolutionary dynamics and disease threats to biodiversity. Trends Ecol Evol 18:589-596

Anderson RM, May RM (1979) Population biology of infectious diseases: Part I. Nature 280:361-367

Ariel E (1997) Pathology and serological aspects of Bohle iridovirus infections in six selected water-associated reptiles in North Queensland. PhD thesis, James Cook University, Townsville

Ariel E, Owens L (1997) Epizootic mortalities in tilapia Oreochromis mossambicus. Dis Aquat Org 29:1-6

Ariel E, Kielgast J, Svart HE, Larsen K, Tapiovaara H, Bang Jensen B, Holopainen R (2009) Ranavirus in wild edible frogs Pelophylax kl. esculentus in Denmark. Dis Aquat Org 85:7-14

Balseiro A, Dalton KP, Del Cerro A, Marquez I, Parra F, Prieto JM, Casias R (2009) Outbreak of common midwife toad virus in alpine newts (Mesotriton alpestris cyreni) and common midwife toads (Alytes obstetricans) in northern Spain: comparative pathological study of an emerging ranavirus. Vet J (in press) doi:10.1016/j.tvjl.2009.07.038

Bang Jensen B, Ersbøll AK, Ariel E (2009) Susceptibility of pike Esox lucius to a panel of Ranavirus isolates. Dis Aquat Org 83:169-179
Bancroft BA, Baker NJ, Blaustein AR (2008) A meta-analysis of the effects of ultraviolet $B$ radiation and its synergistic interactions with $\mathrm{pH}$, contaminants, and disease on amphibian survival. Conserv Biol 22:987-996

Belden LK, Kiesecker JM (2005) Glucocorticosteroid hormone treatment of larval treefrogs increases infection by Alaria sp. trematode cercariae. J Parasitol 91:686-688

Berger L, Speare R, Daszak P, Green DE and others (1998) Chytridiomycosis causes amphibian mortality associated with population declines in the rain forests of Australia and Central America. Proc Natl Acad Sci USA 95:9031-9036

Berna HJ (1990) Ecology and life history of the tiger salamander Ambystoma tigrinum nebulosum Hallowell on the Kaibab Plateau. MS thesis, Arizona State University, Tempe, AZ

Bollinger TK, Mao JH, Schock D, Brigham RM, Chinchar VG (1999) Pathology, isolation, and preliminary molecular characterization of a novel iridovirus from tiger salamanders in Saskatchewan. J Wildl Dis 35:413-429

Boone M, Bridges C (2003) Effects of pesticides on amphibian populations. In: Semlitsch RD (ed) Amphibian conservation. Smithsonian Institute, Washington, DC, p 187-198

Brem FMR, Lips KR (2008) Batrachochytrium dendrobatidis infection patterns among Panamanian amphibian species, habitats and elevations during epizootic and enzootic stages. Dis Aquat Org 81:189-202

Brunner JL, Schock DM, Davidson EW, Collins JP (2004) Intraspecific reservoirs: complex life history and the persistence of a lethal ranavirus. Ecology 85:560-566

> Brunner JL, Richards K, Collins JP (2005) Dose and host characteristics influence virulence of ranavirus infections. Oecologia 144:399-406

- Brunner JL, Schock DM, Collins JP (2007) Transmission dynamics of the amphibian ranavirus Ambystoma tigrinum virus. Dis Aquat Org 77:87-95

Bryan LK, Baldwin CA, Gray MJ, Miller DL (2009) Efficacy of select disinfectants at inactivating Ranavirus. Dis Aquat Org 84:89-94

Burton EC, Miller DL, Styer EL, Gray MJ (2008) Amphibian ocular malformation associated with Frog virus 3. Vet J 177:442-444

Caipang CM, Takano T, Hirono I, Aoki T (2006) Genetic vaccines protect red seabream, Pagrus major, upon challenge with red seabream iridovirus (RSIV). Fish Shellfish Immunol 21:130-138

Canadian Ministry of Natural Resources (CMNR) (2009) Bait for personal use. Available at: www.mnr.gov.on.ca/en/ Business/LetsFish/2ColumnSubPage/STEL02_165361.html (accessed on 29 June 2009)

Carey C, Cohen N, Rollins-Smith L (1999) Amphibian declines: an immunological perspective. Dev Comp Immunol 23: $459-472$

Carey C, Bradford DE, Brunner JL, Collins JP and others (2003a) Biotic factors in amphibian declines. In: Linder G, Krest SK, Sparling DW (eds) Amphibian declines: an integrated analysis of multiple stressor effects. Society of Environmental Toxicology and Chemistry, Pensacola, FL, p 153-208

Carey C, Pessier AP, Peace AD (2003b) Pathogens, infectious disease, and immune defenses. In: Semlitsch RD (ed) Amphibian conservation. Smithsonian Institute, Washington, DC, p 127-136

Chinchar VG (2002) Ranaviruses (family Iridoviridae): emerging cold-blooded killers. Arch Virol 147:447-470

Chinchar VG, Hyatt AD (2008) Iridoviruses: general features. In: Mahy BWJ, Van Regenmortel MHV (eds) Encyclopedia of virology, Vol 3. Elsevier, Oxford, p 167-174

Chinchar VG, Bryan L, Wang J, Long S, Chinchar GD (2003) 
Induction of apoptosis in frog virus 3-infected cells. Virology 306:303-312

Chinchar VG, Essbauer S, He JG, Hyatt A, Miyazaki T, Seligy V, Williams T (2005) Iridoviridae. In: Fauguet CM, Mayo MA, Maniloff J, Desselberger U, Ball LA (eds) Virus taxonomy: 8th report of the international committee on the taxonomy of viruses. Elsevier, London, p 163-175

Chinchar VG, Hyatt AD, Miyazaki T, Williams T (2009) Family Iridoviridae: poor viral relations no longer. In: Van Etten JL (ed) Current topics in microbiology and immunology, Vol 328. Lesser known large dsDNA viruses. Springer-Verlag, Berlin, p 123-170

Christin MS, Gendron AD, Brousseau P, Menard L and others (2003) Effects of agricultural pesticides on the immune system of Rana pipiens and on its resistance to parasitic infection. Environ Toxicol Chem 22:1127-1133

Christin MS, Menard L, Gendron AD, Ruby S and others (2004) Effects of agricultural pesticides on the immune system of Xenopus laevis and Rana pipiens. Aquat Toxicol 67:33-43

Collins JP, Storfer A (2003) Global amphibian declines: sorting the hypotheses. Divers Distrib 9:89-98

Collins JP, Jones TR, Berna HJ (1988) Conserving geneticallydistinctive populations: the case of the Huachuca tiger salamanders (Ambystoma tigrinum stebbinsi Lowe). In: Szaro RC, Severson KC, Patton DR (eds) Management of amphibians, reptiles, and small mammals in North America. GTR-RM-166, US Department of Agriculture Forest Service, Rocky Mountain Forest and Range Experiment Station, Fort Collins, CO, p 45-53

Collins JP, Brunner JL, Jancovich JK, Schock DM (2004) A model host-pathogen system for studying infectious disease dynamics in amphibians: tiger salamanders (Ambystoma tigrinum) and Ambystoma tigrinum virus. Herpetol J 14:195-200

Converse KA, Green DE (2005a) Diseases of salamanders. In: Majumdar SK, Huffman JE, Brenner FJ, Panah AI (eds) Wildlife diseases: landscape epidemiology, spatial distribution and utilization of remote sensing technology. Pennsylvania Academy of Science, Easton, PA, p 118-130

Converse KA, Green DE (2005b) Diseases of tadpoles. In: Majumdar SK, Huffman JE, Brenner FJ, Panah AI (eds) Wildlife diseases: landscape epidemiology, spatial distribution and utilization of remote sensing technology. Pennsylvania Academy of Science, Easton, PA, p 72-88

Cooper EL, Wright RK, Klempau AE, Smith CT (1992) Hibernation alters the frog immune system. Cryobiology 29: 616-631

Copeland JE, Mears GL, Caldwell RS (2009) Salamanders as fishing bait in the Blue Ridge Physiographic Province of East Tennessee. J Tenn Acad Sci 84:52-54

Cullen BR, Owens L (2002) Experimental challenge and clinical cases of Bohle iridovirus (BIV) in native Australian anurans. Dis Aquat Org 49:83-92

Cullen BR, Owens L, Whittington RJ (1995) Experimental infection of Australian anurans (Limnodynastes terraereginae and Litoria latopalmata) with Bohle iridovirus. Dis Aquat Org 23:83-92

Cunningham AA, Langton TES, Bennett PM, Drury SEN, Gough RE, Kirkwood JK (1993) Unusual mortality associated with poxvirus-like particles in frogs (Rana temporaria). Vet Rec 133:141-142

Cunningham AA, Langton TES, Bennett PM, Lewin JF, Drury SEN, Gough RE, MacGregor SK (1996) Pathological and microbiological findings from incidents of unusual mortality of the common frog (Rana temporaria). Philos Trans R Soc Lond B 351:1539-1557
Cunningham AA, Daszak P, Rodriguez JP (2003) Pathogen pollution: defining a parasitological threat to biodiversity conservation. J Parasitol 89(Suppl):78-83

> Cunningham AA, Hyatt AD, Russell P, Bennett PM (2007a) Emerging epidemic diseases of frogs in Britain are dependent on the source of ranavirus agent and the route of exposure. Epidemiol Infect 135:1200-1212

Cunningham AA, Hyatt AD, Russell P, Bennett PM (2007b) Experimental transmission of a ranavirus disease of common toads (Bufo bufo) to common frogs (Rana temporaria). Epidemiol Infect 135:1213-1216

- Cunningham AA, Tems CA, Russell PH (2008) Immunohistochemical demonstration of ranavirus antigen in the tissues of infected frogs (Rana temporaria) with systemic haemorrhagic or cutaneous ulcerative disease. J Comp Pathol 138:3-11

Daszak P, Cunningham AA, Hyatt AD (2000) Wildlife ecology - emerging infectious diseases of wildlife: threats to biodiversity and human health. Science 287:443-449

> Daszak P, Cunningham AA, Hyatt AD (2001) Anthropogenic environmental change and the emergence of infectious diseases in wildlife. Acta Trop 78:103-116

> Daszak P, Cunningham AA, Hyatt AD (2003) Infectious disease and amphibian population declines. Divers Distrib 9: 141-150

Daszak P, Strieby A, Cunningham AA, Longcore JE, Brown CC, Porter D (2004) Experimental evidence that the bullfrog (Rana catesbeiana) is a potential carrier of chytridiomycosis, an emerging fungal disease of amphibians. Herpetol J 14:201-207

Davidson C, Knapp RA (2007) Multiple stressors and amphibian declines: dual impacts of pesticides and fish on yellow-legged frogs. Ecol Appl 17:587-597

$>$ Davidson C, Shaffer HB, Jennings MR (2002) Spatial tests of the pesticide drift, habitat destruction, UV-B, and climatechange hypotheses for California amphibian declines. Conserv Biol 16:1588-1601

> Davis AK, Yabsley MJ, Keel MK, Maerz JC (2007) Discovery of a novel alveolate pathogen affecting southern leopard frogs in Georgia: description of the disease and host effects. EcoHealth 4:310-317

de Castro F, Bolker B (2005) Mechanisms of disease-induced extinction. Ecol Lett 8:117-126

De Voe R, Geissler K, Elmore S, Rotstein D, Lewbart G, Guy J (2004) Ranavirus-associated morbidity and mortality in a group of captive eastern box turtles (Terrapene carolina carolina). J Zoo Wildl Med 35:534-543

> Docherty DE, Meteyer CU, Wang J, Mao J, Case S, Chinchar GD (2003) Diagnostic and molecular evaluation of three iridovirus-associated salamander mortality events. J Wildl Dis 39:556-566

Driskell EA, Miller DL, Swist SL, Gyimesi ZS (2009) PCR detection of Ranavirus in adult anurans from the Louisville Zoological Garden. J Zoo Wildl Med 40:559-563

- Drury SE, Gough RE, Cunningham AA (1995) Isolation of an iridovirus-like agent from common frogs (Rana temporaria). Vet Rec 137:72-73

Ducoroy P, Lesourd M, Padros MR, Tournefier A (1999) Natural and induced apoptosis during lymphocyte development in the axolotl. Dev Comp Immunol 23:241-252

> Duffus ALJ, Pauli BD, Wozney K, Brunetti CR, Berrill M (2008) Frog virus 3-like infections in aquatic amphibian communities. J Wildl Dis 44:109-120

Eaton HE, Metcalf J, Penny E, Tcherepanov V, Upton C, Brunetti CR (2007) Comparative genomic analysis of the family Iridoviridae: re-annotating and defining the core set of iridovirus genes. Virol J 4:1-17 
European Commission (2009) RANA: identifying disease risk to native fish from ornamental fish species. Available at: http://ec.europa.eu/research/fp6/ssp/rana_en.htm (accessed on 1 July 2009)

Farris JS, Kallersjo M, Kluge AG, Bult C (1995) Constructing a significance test for incongruence. Syst Biol 44:570-572

Flajnik MF, Hsu E, Kaufman JF, Dupasquier L (1987) Changes in the immune system during metamorphosis of Xenopus. Immunol Today 8:58-64

Forson DD, Storfer A (2006a) Atrazine increases ranavirus susceptibility in the tiger salamander, Ambystoma tigrinum. Ecol Appl 16:2325-2332

Forson D, Storfer A (2006b) Effects of atrazine and iridovirus infection on survival and life-history traits of the long-toed salamander (Ambystoma macrodactylum). Environ Toxicol Chem 25:168-173

Fox SF, Greer AL, Torres-Cervantes R, Collins JP (2006) First case of ranavirus-associated morbidity and mortality in natural populations of the South American frog Atelognathus patagonicus. Dis Aquat Org 72:87-92

Gahl MK, Calhoun AJK (2008) Landscape setting and risk of Ranavirus mortality events. Biol Conserv 141:2679-2689

> Gantress J, Maniero GD, Cohen N, Robert J (2003) Development and characterization of a model system to study amphibian immune responses to iridoviruses. Virology 311: 254-262

Garner TWJ, Perkins MW, Govindarajulu P, Seglie D, Walker S, Cunningham AA, Fisher MC (2006) The emerging amphibian pathogen Batrachochytrium dendrobatidis globally infects introduced populations of the North American bullfrog, Rana catesbeiana. Biol Lett 2:455-459

> Gendron AD, Marcogliese DJ, Barbeau S, Christin MS and others (2003) Exposure of leopard frogs to a pesticide mixture affects life history characteristics of the lungworm Rhabdias ranae. Oecologia 135:469-476

Glennemeier KA, Denver RJ (2002) Role for corticoids in mediating the response of Rana pipiens tadpoles to intraspecific competition. J Exp Zool 292:32-40

> Goldman N, Anderson JP, Rodrigo AG (2000) Likelihoodbased tests of topologies in phylogenetics. Syst Biol 49: 652-670

Gosner KL (1960) A simplified table for staging anuran embryos and larvae with notes and identification. Herpetologica 16:183-190

> Granoff A, Came PE, Rafferty KA (1965) The isolation and properties of viruses from Rana pipiens: their possible relationship to the renal adenocarcinoma of the leopard frog. Ann NY Acad Sci 126:237-255

Gray MJ, Smith LM, Brenes R (2004a) Effects of agricultural cultivation on demographics of Southern High Plains amphibians. Conserv Biol 18:1368-1377

Gray MJ, Smith LM, Leyva RI (2004b) Influence of agricultural landscape structure on a Southern High Plains, USA, amphibian assemblage. Landscape Ecol 19:719-729

Gray MJ, Miller DL, Schmutzer AC, Baldwin CA (2007) Frog virus 3 prevalence in tadpole populations inhabiting cattle-access and non-access wetlands in Tennessee, USA. Dis Aquat Org 77:97-103

Gray MJ, Miller DL, Hoverman JT (2009) First report of Ranavirus infecting lungless salamanders. Herpetol Rev 40: 316-319

Green DE, Converse KA (2005) Diseases of frogs and toads. In: Majumdar SK, Huffman JE, Brenner FJ, Panah AI (eds) Wildlife diseases: landscape epidemiology, spatial distribution and utilization of remote sensing technology. Pennsylvania Academy of Science, Easton, PA, p 89-117

Green DE, Converse KA, Schrader AK (2002) Epizootiology of sixty-four amphibian morbidity and mortality events in the USA, 1996-2001. Ann NY Acad Sci 969:323-339

Green DE, Gray MJ, Miller DL (2009) Disease monitoring and biosecurity. In: Dodd CK (ed) Amphibian ecology and conservation: a handbook of techniques. Oxford University Press, Oxford, p 481-506

Greer AL, Collins JP (2007) Sensitivity of a diagnostic test for amphibian ranavinus varies with sampling protocol. J Wildl Dis 43:525-532

Greer AL, Collins JP (2008) Habitat fragmentation as a result of biotic and abiotic factors controls pathogen transmission throughout a host population. J Anim Ecol 77:364-369

Greer AL, Berrill M, Wilson PJ (2005) Five amphibian mortality events associated with ranavirus infection in south central Ontario, Canada. Dis Aquat Org 67:9-14

Greer AL, Briggs CI, Collins JP (2008) Testing a key assumption of host-pathogen theory: density and disease transmission. Oikos 117:1667-1673

Greer AL, Brunner JL, Collins JP (2009) Spatial and temporal patterns of Ambystoma tigrinum virus (ATV) prevalence in tiger salamanders Ambystoma tigrinum nebulosum. Dis Aquat Org 85:1-6

$>$ Gruia-Gray J, Desser SS (1992) Cytopathological observations and epizootiology of frog erythrocytic virus in bullfrogs (Rana catesbeiana). J Wildl Dis 28:34-41

Hanselmann R, Rodriguez A, Lampo M, Fajardo-Ramos L and others (2004) Presence of an emerging pathogen of amphibians in introduced bullfrogs Rana catesbeiana in Venezuela. Biol Conserv 120:115-119

Hanski I (1999) Metapopulation ecology. Oxford University Press, New York

Harp EM, Petranka JW (2006) Ranavirus in wood frogs (Rana sylvatica): potential sources of transmission within and between ponds. J Wildl Dis 42:307-318

- Hayes TB, Case P, Chui S, Chung D and others (2006) Pesticide mixtures, endocrine disruption, and amphibian declines: Are we underestimating the impact? Environ Health Perspect 114:40-50

> He JG, Lu L, Deng M, He HH and others (2002) Sequence analysis of the complete genome of an iridovirus isolated from the tiger frog. Virology 292:185-197

Hedrick RP, McDowell TS, Ahne W, Torhy C, Dekinkelin P (1992) Properties of three iridovirus-like agents associated with systemic infections of fish. Dis Aquat Org 13:203-209

Hess G (1996) Disease in metapopulation models: implications for conservation. Ecology 77:1617-1632

Hill RW, Wyse GA (1989) Animal physiology. Harper and Row, New York

Hoffman EA, Pfennig DW (1999) Proximate causes of cannibalistic polyphenism in larval tiger salamanders. Ecology 80:1076-1080

> Holopainen R, Ohlemeyer S, Schütze H, Bergmann SM, Tapiovaara H (2009) Ranavirus phylogeny and differentiation based on major capsid protein, DNA polymerase and neurofilament triplet H1-like protein genes. Dis Aquat Org 85: 81-91

> Houlahan JE, Findlay CS, Schmidt BR, Meyer AH, Kuzmin SL (2000) Quantitative evidence for global amphibian population declines. Nature 404:752-755

Hyatt AD, Gould AR, Zupanovic Z, Cunningham AA and others (2000) Comparative studies of piscine and amphibian iridoviruses. Arch Virol 145:301-331

Hyatt AD, Williamson M, Coupar BEH, Middleton D and others (2002) First identification of a ranavirus from green pythons (Chondropython viridis). J Wildl Dis 38:239-252 > Jancovich JK, Davidson EW, Morado JF, Jacobs BL, Collins JP (1997) Isolation of a lethal virus from the endangered tiger 
salamander Ambystoma tigrinum stebbinsi. Dis Aquat Org 31:161-167

Jancovich JK, Davidson EW, Seiler A, Jacobs BL, Collins JP (2001) Transmission of the Ambystoma tigrinum virus to alternative hosts. Dis Aquat Org 46:159-163

> Jancovich JK, Mao JH, Chinchar VG, Wyatt C and others (2003) Genomic sequence of a ranavirus (family Iridoviridae) associated with salamander mortalities in North America. Virology 316:90-103

Jancovich JK, Davidson EW, Parameswaran N, Mao J and others (2005) Evidence for emergence of an amphibian iridoviral disease because of human-enhanced spread. Mol Ecol 14:213-224

$>$ Jofre MB, Karasov WH (1999) Direct effect of ammonia on three species of North American anuran amphibians. Environ Toxicol Chem 18:1806-1812

Johnson AJ, Pessier AP, Wellehan JFX, Childress A and others (2008) Ranavirus infection of free-ranging and captive box turtles and tortoises in the United States. J Wildl Dis 44:851-863

Kattenbelt JA, Hyatt AD, Gould AR (2000) Recovery of ranavirus dsDNA from formalin-fixed archival material. Dis Aquat Org 39:151-154

Knutson MG, Sauer JR, Olsen DA, Mossman MJ, Hemesath LM, Lannoo MJ (1999) Effects of landscape composition and wetland fragmentation on frog and toad abundance and species richness in Iowa and Wisconsin, USA. Conserv Biol 13:1437-1446

Kolozsvary MB, Swihart RK (1999) Habitat fragmentation and the distribution of amphibians: patch and landscape correlates in farmland. Can J Zool 77:1288-1299

> Langdon JS (1989) Experimental transmission and pathogenicity of epizootic hematopoietic necrosis virus (EHNV) in redfin perch, Perca fluviatilis L. and 11 other teleosts. J Fish Dis 12:295-310

> Langdon JS, Humphrey JD, Williams LM, Hyatt AD, Westbury HA (1986) First virus isolation from Australian fish: an iridovirus-like pathogen from redfin perch, Perca fluviatilis L. J Fish Dis 9:263-268

Lloyd-Smith JO, Cross PC, Briggs CJ, Daugherty M and others (2005a) Should we expect population thresholds for wildlife diseases? Trends Ecol Evol 20:511-519

Lloyd-Smith JO, Schreiber SJ, Getz WM (2005b) Superspreading and the effect of individual variation on disease emergence. Nature 438:355-359

Majji S, LaPatra S, Long SM, Sample R, Bryan L, Sinning A, Chinchar VG (2006) Rana catesbeiana virus Z (RCV-Z): a novel pathogenic ranavirus. Dis Aquat Org 73:1-11

- Maniero GD, Carey C (1997) Changes in selected aspects of immune function in the leopard frog, Rana pipiens, associated with exposure to cold. J Comp Physiol B 167:256-263

- Maniero GD, Morales H, Gantress J, Robert J (2006) Generation of a long-lasting, protective, and neutralizing antibody response to the ranavirus FV3 by the frog Xenopus. Dev Comp Immunol 30:649-657

Mao J, Tham TN, Gentry GA, Aubertin A, Chinchar VG (1996) Cloning, sequence analysis, and expression of the major capsid protein of the iridovirus frog virus 3. Virology 216:431-436

Mao J, Green DE, Fellers G, Chinchar VG (1999) Molecular characterization of iridoviruses isolated from sympatric amphibians and fish. Virus Res 63:45-52

Marschang RE, Becher P, Posthaus H, Wild P and others (1999) Isolation and characterization of an iridovirus from Hermann's tortoises (Testudo hermanni). Arch Virol 144: 1909-1922

Marschang RE, Braun S, Becher P (2005) Isolation of a rana- virus from a gecko (Uroplatus fimbriatus). J Zoo Wildl Med 36:295-300

Marsh DM, Trenham PC (2001) Metapopulation dynamics and amphibian conservation. Conserv Biol 15:40-49

> McCallum H, Barlow N, Hone J (2001) How should pathogen transmission be modelled? Trends Ecol Evol 16:295-300

> Miller DL, Rajeev S, Gray MJ, Baldwin CA (2007) Frog virus 3 infection, cultured American bullfrogs. Emerg Infect Dis 13:342-343

Miller DL, Rajeev S, Brookins M, Cook J, Whittington L, Baldwin CA (2008) Concurrent infection with Ranavirus, Batrachochytrium dendrobatidis, and Aeromonas in a captive anuran colony. J Zoo Wildl Med 39:445-449

Miller DL, Gray MJ, Rajeev S, Schmutzer AC, Burton EC, Merrill A, Baldwin CA (2009) Pathological findings in larval and juvenile anurans inhabiting farm ponds in Tennessee, USA. J Wildl Dis 45:314-324

> Miodoński AJ, Bigaj J, Mika J, Płytycz B (1996) Season-specific thymic architecture in the frog, Rana temporaria: SEM studies. Dev Comp Immunol 20:129-137

> Moody NJG, Owens L (1994) Experimental demonstration of the pathogenicity of a frog virus, Bohle iridovirus, for a fish species, barramundi Lates calcarifer. Dis Aquat Org 18: 95-102

Muths E, Gallant AL, Campbell EHC, Battaglin WA and others (2006) The Amphibian Research and Monitoring Initiative (ARMI): 5-year report. US Geological Survey Scientific Investigations Report 2006-5224

Muths E, Pilliod DS, Livo LJ (2008) Distribution and environmental limitations of an amphibian pathogen in the Rocky Mountains, USA. Biol Conserv 141:1484-1492

Nakajima K, Ito T, Kurita J, Kawakami H and others (2002) Effectiveness of a vaccine against red sea bream iridoviral disease in various cultured marine fish under laboratory conditions. Fish Pathol 37:90-91

Ottaviani E, Franceschi C (1996) The neuroimmunology of stress from invertebrates to man. Prog Neurobiol 48: $421-440$

> Pallister J, Gould A, Harrison D, Hyatt A, Jancovich J, Heine $\mathrm{H}$ (2007) Development of real-time PCR assays for the detection and differentiation of Australian and European ranaviruses. J Fish Dis 30:427-438

> Parris MJ, Davis A, Collins JP (2004) Single-host pathogen effects on mortality and behavioral responses to predators in salamanders (Urodela: Ambystomatidae). Can J Zool 82:1477-1483

Parris MJ, Storfer A, Collins JP, Davidson EW (2005) Lifehistory responses to pathogens in tiger salamander (Ambystoma tigrinum) larvae. J Herpetol 39:366-372

Pasmans F, Blahak S, Martel A, Pantchev N, Zwart P (2008) Ranavirus-associated mass mortality in imported red tailed knobby newts (Tylototriton kweichowensis): a case report. Vet J 176:257-259

> Pearman PB, Garner TWJ (2005) Susceptibility of Italian agile frog populations to an emerging strain of Ranavirus parallels population genetic diversity. Ecol Lett 8:401-408

> Pearman PB, Garner TWJ, Straub M, Greber UF (2004) Response of the Italian agile frog (Rana latastei) to a Ranavirus, frog virus 3: a model for viral emergence in naive populations. J Wildl Dis 40:660-669

> Pfennig DW, Murphy PJ (2000) Character displacement in polyphenic tadpoles. Evolution 54:1738-1749

Pfennig DW, Loeb MLG, Collins JP (1991) Pathogens as a factor limiting the spread of cannibalism in tiger salamanders. Oecologia 88:161-166

> Picco AM, Collins JP (2008) Amphibian commerce as a likely source of pathogen pollution. Conserv Biol 22:1582-1589 
Picco AM, Brunner JL, Collins JP (2007) Susceptibility of the endangered California tiger salamander, Ambystoma californiense, to Ranavirus infection. J Wildl Dis 43:286-290

Pounds JA, Bustamante MR, Coloma LA, Consuegra JA and others (2006) Widespread amphibian extinctions from epidemic disease driven by global warming. Nature 439: 161-167

Power AG, Mitchell CE (2004) Pathogen spillover in disease epidemics. Am Nat 164:S79-S89

Rachowicz LJ, Hero JM, Alford RA, Taylor JW and others (2005) The novel and endemic pathogen hypotheses: competing explanations for the origin of emerging infectious diseases of wildlife. Conserv Biol 19:1441-1448

Raffel TR, Rohr JR, Kiesecker JM, Hudson PJ (2006) Negative effects of changing temperature on amphibian immunity under field conditions. Funct Ecol 20:819-828

Rafferty KA (1965) The cultivation of inclusion-associated viruses from Lucke tumor frogs. Ann NY Acad Sci 126:3-21

Relyea RA (2004) Growth and survival of five amphibian species exposed to combinations of pesticides. Environ Toxicol Chem 23:1737-1742

Relyea R, Hoverman J (2006) Assessing the ecology in ecotoxicology: a review and synthesis in freshwater systems. Ecol Lett 9:1157-1171

Ridenhour BJ, Storfer AT (2008) Geographically variable selection in Ambystoma tigrinum virus (Iridoviridae) throughout the western USA. J Evol Biol 21:1151-1159

Rittenhouse TAG, Semlitsch RD (2006) Grasslands as movement barriers for a forest-associated salamander: migration behavior of adult and juvenile salamanders at a distinct habitat edge. Biol Conserv 131:14-22

Robert J, Morales H, Buck W, Cohen N, Marr S, Gantress J (2005) Adaptive immunity and histopathology in frog virus 3-infected Xenopus. Virology 332:667-675

Robert J, Abramowitz L, Gantress J, Morales HD (2007) Xenopus laevis: A possible vector of ranavirus infection? J Wildl Dis 43:645-652

Rohr JR, Kerby J, Sih A (2006) Community ecology theory as a framework for predicting contaminant effects. Trends Ecol Evol 21:606-613

Rohr JR, Schotthoefer AM, Raffel TR, Carrick HJ and others (2008) Agrochemicals increase trematode infections in a declining amphibian species. Nature 455:1235-1239

Rojas S, Richards K, Jancovich JK, Davidson EW (2005) Influence of temperature on Ranavirus infection in larval salamanders Ambystoma tigrinum. Dis Aquat Org 63:95-100

Rollins-Smith LA (1998) Metamorphosis and the amphibian immune system. Immunol Rev 166:221-230

Rollins-Smith LA, Blair PJ (1993) The effects of corticosteroid hormones and thyroid hormones on lymphocyte viability and proliferation during development and metamorphosis of Xenopus laevis. Differentiation 54:155-160

Romansic JM, Higashi EM, Diez KA, Blaustein AR (2007) Susceptibility of newly-metamorphosed frogs to a pathogenic water mould (Saprolegnia sp.). Herpetol J 17:161-166

Rot-Nikcevic I, Denver RJ, Wassersug RJ (2005) The influence of visual and tactile stimulation on growth and metamorphosis in anuran larvae. Funct Ecol 19:1008-1016

Rothermel BB, Semlitsch RD (2002) An experimental investigation of landscape resistance of forest versus old-field habitats to emigrating juvenile amphibians. Conserv Biol 16:1324-1332

Rouse JD, Bishop CA, Struger J (1999) Nitrogen pollution: an assessment of its threat to amphibian survival. Environ Health Perspect 107:799-803

Sample R, Bryan L, Long S, Majji S and others (2007) Inhibition of iridovirus protein synthesis and virus replication by antisense morpholino oligonucleotides targeted to the major capsid protein, the $18 \mathrm{kDa}$ immediate-early protein, and a viral homolog of RNA polymerase II. Virology 358: 311-320

Schlaepfer MA, Hoover C, Dodd CK (2005) Challenges in evaluating the impact of the trade in amphibians and reptiles on wild populations. Bioscience 55:256-264

Schloegel LM, Picco AM, Kilpatrick AM, Davies AJ, Hyatt AD, Daszak P (2009) Magnitude of the US trade in amphibians and presence of Batrachochytrium dendrobatidis and ranavirus infection in imported North American bullfrogs (Rana catesbeiana). Biol Conserv 142:1420-1426

Schmutzer AC (2007) Influences of cattle on community structure and pathogen prevalence in larval amphibians on the Cumberland Plateau, Tennessee. MS thesis, University of Tennessee, Knoxville, TN

Schmutzer AC, Gray MJ, Burton EC, Miller DL (2008) Impacts of cattle on amphibian larvae and the aquatic environment. Freshw Biol 53:2613-2625

Schock DM, Bollinger TK (2005) An apparent decline of northern leopard frogs (Rana pipiens) on the Rafferty Dam mitigation lands near Estevan, Saskatchewan. Blue Jay 63:144-154

Schock DM, Bollinger TK, Chinchar VG, Jancovich JK, Collins JP (2008) Experimental evidence that amphibian ranaviruses are multi-host pathogens. Copeia 2008(1):133-143

> Semlitsch RD, Bodie JR (2003) Biological criteria for buffer zones around wetlands and riparian habitats for amphibians and reptiles. Conserv Biol 17:1219-1228

Shimodaira H, Hasegawa M (1999) Multiple comparisons of log-likelihoods with applications to phylogenetic inference. Mol Biol Evol 16:1114-1116

Speare R, Smith JR (1992) An iridovirus-like agent isolated from the ornate burrowing frog Limnodynastes ornatus in northern Australia. Dis Aquat Org 14:51-57

St-Amour V, Lesbarrères D (2007) Genetic evidence of Ranavirus in toe clips: an alternative to lethal sampling methods. Conserv Genet 8:1247-1250

St-Amour V, Wong WM, Garner TWJ, Lesbarrères D (2008) Anthropogenic influence on prevalence of 2 amphibian pathogens. Emerg Infect Dis 14:1175-1176

Storfer A, Alfaro ME, Ridenhour BJ, Jancovich JK, Mech SG, Parris MJ, Collins JP (2007) Phylogenetic concordance analysis shows an emerging pathogen is novel and endemic. Ecol Lett 10:1075-1083

Stuart SN, Chanson JS, Cox NA, Young BE, Rodrigues ASL, Fischman DL, Waller RW (2004) Status and trends of amphibian declines and extinctions worldwide. Science 306:1783-1786

Tan WGH, Barkman TJ, Chinchar VG, Essani K (2004) Comparative genomic analyses of frog virus 3, type species of the genus Ranavirus (family Iridoviridae). Virology 323: $70-84$

Teacher AGF (2008) Population and immune competent genetic variation: a field-based study. $\mathrm{PhD}$ thesis, University of London, Queen Mary, London

> Teacher AGF, Garner TWJ, Nichols RA (2009a) Evidence for directional selection at a novel major histocompatibility class I marker in wild common frogs (Rana temporaria) exposed to a viral pathogen (Ranavirus). PLoS One 4:e4616, doi:10.1371/journal.pone.0004616

- Teacher AGF, Garner TWJ, Nichols RA (2009b) Population genetic patterns suggest a behavioural change in wild common frogs (Rana temporaria) following disease outbreaks (Ranavirus). Mol Ecol 18:3163-3172

> Tidona CA, Schnitzler P, Kehm R, Darai G (1998) Is the major capsid protein of iridoviruses a suitable target for the 
study of viral evolution? Virus Genes 16:59-66

Tweedell K, Granoff A (1968) Viruses and renal carcinoma of Rana pipiens. V. Effect of frog virus 3 on developing frog embryos and larvae. J Natl Cancer Inst 40:407-410

Une Y, Sakuma A, Matsueda H, Nakai K, Murakami M (2009) Ranavirus outbreak in North American bullfrogs (Rana catesbeiana), Japan, 2008. Emerg Infect Dis 15: 1146-1147

> Wake DB, Vredenburg VT (2008) Are we in the midst of the sixth mass extinction? A view from the world of amphibians. Proc Natl Acad Sci USA 105:11466-11473

Wang JW, Deng RQ, Wang XZ, Huang YS and others (2003) Cladistic analysis of iridoviruses based on protein and DNA sequences. Arch Virol 148:2181-2194

Westhouse RA, Jacobson ER, Harris RK, Winter KR, Homer BL (1996) Respiratory and pharyngo-esophageal iridovirus infection in a gopher tortoise (Gopherus polyphemus). J Wildl Dis 32:682-686

Wilbur HM (1984) Complex life cycles and community organization in amphibians. In: Price PW, Slobodchikoff CN, Gaud WS (eds) A new ecology: novel approaches to interactive systems. Wiley, New York, p 196-224

Williams T, Barbosa-Solomieu V, Chinchar GD (2005) A decade of advances in iridovirus research. In: Maramorosch K, Shatkin A (eds) Advances in virus research, Vol 65. Academic Press, New York, p 173-248

Editorial responsibility: Andrew Cunningham, London, UK
Wolf K, Bullock GL, Dunbar CE, Quimby MC (1968) Tadpole edema virus: a viscerotropic pathogen for anuran amphibians. J Infect Dis 118:253-262

> Woodroffe R (1999) Managing threats to wild animals. Anim Conserv 2:185-193

Wright KM (2001) Surgical techniques. In: Wright KM, Whitaker BR (eds) Amphibian medicine and captive husbandry. Krieger Publishing Company, Malabar, FL, p 273-283

Xie J, Lü L, Deng M, Weng S and others (2005) Inhibition of reporter gene and iridovirus-tiger frog virus in fish cell by RNA interference. Virology 338:43-52

Yuan JS, Reed A, Chen F, Stewart CN Jr (2006) Statistical analysis of real-time PCR data. BMC Bioinformatics 7:85-97

Zabik JM, Seiber JN (1993) Atmospheric transport of organophosphate pesticides from California Central Valley to the Sierra-Nevada Mountains. J Environ Qual 22:80-90

Zhang QY, Xiao F, Li ZQ, Gui JF, Mao J, Chinchar VG (2001) Characterization of an iridovirus from the cultured pig frog Rana grylio with lethal syndrome. Dis Aquat Org 48:27-36

Zhao Z, Teng Y, Liu H, Lin X, Wang K, Jiang Y, Chen H (2007) Characterization of a late gene encoding for MCP in softshelled turtle iridovirus (STIV). Virus Res 129:135-144

Zupanovic Z, Lopez G, Hyatt AD, Green B and others (1998) Giant toads Bufo marinus in Australia and Venezuela have antibodies against 'ranaviruses'. Dis Aquat Org 32:1-8

Submitted: March 30, 2009; Accepted: September 1, 2009 Proofs received from author(s): November 13, 2009 